\title{
Dementia in Movement Disorders
}

\author{
H. Teräväinen, M. Hietanen, J. Stoessl and D.B. Calne
}

\begin{abstract}
Of all the movement disorders, Huntington's disease has been most consistently associated with dementia, while it is only over the last decade that intellectual and cognitive decline have been recognized as common features of Parkinson's disease. It is now known that the pathology in these two conditions reflects differential involvement of the striatum. The Huntington lesion is primarily in the caudate, while the Parkinson lesion preferentially affects the putamen. Both conditions have more diffuse pathology, and dementia may also occur in a wide range of other extrapyramidal diseases, such as progressive supranuclear palsy, the parkinsonism-dementia complex of Guam, and certain spinocerebellar degenerations. Clinicopathological correlations will be reviewed in these disorders of primarily subcortical pathology, and comparisons will be made with Alzheimer's disease, a disorder of predominantly cortical pathology.
\end{abstract}

RÉSUMÉ: La démence dans les désordres du mouvement. De tous les désordres du mouvement, la maladie de Huntington a été celle qui a été le plus fréquemment associée à la démence. Ce n'est que depuis la dernière décennie que le déclin intellectuel et cognitif est reconnu comme une manifestation fréquente de la maladie de Parkinson. Nous savons maintenant que la pathologie de ces deux affections reflère une atteinte différentielle du striatum. La lésion de la maladie de Huntington est principalement au niveau du noyau caudé, alors que, dans la maladie de Parkinson, elle atteint préférentiellement le putamen. Les lésions dans ces deux maladies sont plus diffuses et la démence peut aussi survenir dans une grande variété d'autres maladies extrapyramidales, comme la paralysie supranucléaire progressive, le complexe parkinsonisme-démence de Guam et certaines dégénérescences spinocérébelleuses. Nous revoyons les corrélations clinicopathologiques dans ces maladies impliquant principalement une pathologie sous-corticale et nous présentons des comparaisons avec la maladie d'Alzheimer, une affection dont la pathologie est située principalement au niveau du cortex.

Can. J. Neurol. Sci. 1986; 13:546-558

While dementia occurs in many diseases, there is a group of disorders of mainly unknown etiology characterized primarily by degenerative changes in the nervous system. Of all the movement disorders, Huntington's disease has been most consistently associated with dementia, it is only over the last decade that intellectual and cognitive decline have been recognized as common manifestations in Parkinson's disease. It is now known that the striatal pathology in these two conditions represents opposite poles, the Huntington lesion being primarily in the caudate, while the Parkinson pathology is predominantly in the putamen. Both conditions have more diffuse pathology, and dementia may also occur in a wide range of other extrapyramidal diseases such as progressive supranuclear palsy, parkinsonism dementia complex of Guam and certain spinocerebellar degenerations (Table 1). Clinicopathological correlations will be reviewed in these disorders of primarily subcortical pathology, and comparisons will be made with Alzheimer's disease, a disorder of predominantly cortical pathology. It is therefore necessary to start by considering the salient pathological and biochemical features of Alzheimer's disease, for comparative purposes.

\begin{abstract}
Alzheimer's type dementia
We will first briefly review Alzheimer's disease ${ }^{1,2}$ since it is the commonest and most extensively studied dementing illness. Until recently the use of the name Alzheimer's disease was limited to persons below 65 , but now the term is included among the group of primary degenerative dementias (DSM III 1980) (Table 2), and the age is not considered relevant to etiology. ${ }^{3}$ The disease shares numerous clinical features with Pick's disease $^{4}$ and these two diseases are frequently considered as one entity in the current literature, particularly since clinical separation is difficult. On the other hand, these two diseases still warrant differentiation since the pathological findings are regionally disparate and biochemical changes may be different. ${ }^{5}$ In both diseases the neuropathological changes observed affect certain brain regions selectively and show important differences compared to the neuropathology accompanying movement disorders associated with dementia. In Alzheimer's disease the most evident alterations are observed in the frontal, temporal and parietal association cortex, and in the hippocampus. The primary motor, somatosensory and visual cortical areas are relatively preserved, 2.6 .7 .8 .9 .10 .11 .12 and these regional
\end{abstract}

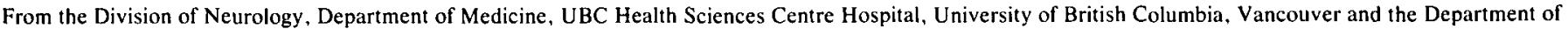
Neurology. University of Helsinki. Finland.

Reprint requests to: Dr. D. Calne, The University of British Columbia, Health Sciences Centre Hospital, 221I Wesbrook Mall, Vancouver, B.C., Canada V6T 1W5 
differences are reflected during life by comparable changes in cerebral glucose metabolism (Fig. 1) (c.f. also ${ }^{13.14 .15 .16}$ ). Alzheimer's disease differs from the various disorders of motor function that may be associated with dementia (Table 1) in that most subcortical cerebral structures are relatively well preserved, though in both categories of illness significant changes may occur in the nucleus basalis of Meynert, ${ }^{17.18 .19 .20 .21 .22}$ amygdala ${ }^{23}$ and locus ceruleus. ${ }^{24.25 .26 .27}$ The subcortical structures are also relatively intact in Pick's disease occupying a somewhat intermediate position, in which the most significant changes are found in the frontal and anterior temporal cortex, although caudate atrophy does occur.

Disappearance of the large cholinergic neurones from the nucleus basalis of Meynert (a part of the substantia innominata) and the associated degeneration of their cortical projections have recently gathered interest because of the suggestion of a causal relationship with dementia. ${ }^{22,28}$ This neuronal loss in

Table 1. Diseases accompanied by dementia

\begin{tabular}{l} 
Primary degenerative \\
Cortical dementias \\
Alzheimer's disease \\
Pick's disease \\
Extrapyramidal disorders \\
$\quad$ Huntington's disease \\
$\quad$ Multiple system atrophies \\
$\quad$ Parkinson's disease \\
$\quad$ Spinocerebellar degenerations \\
$\quad$ Progressive supranuclear palsy \\
$\quad$ Wilson's disease \\
Vascular \\
Binswanger's disease \\
Multi-infarct dementia \\
Infectious \\
General paresis \\
Slow-virus infections \\
Toxic and metabolic \\
Alcoholism \\
BI2 vitamin deficiency \\
Drug intoxications \\
Heavy metal poisoning \\
Hypothyroidism \\
Miscellaneous \\
Anoxic \\
Hydrocephalus \\
Traumatic \\
\hline
\end{tabular}

Table 2. Clinical criteria for dementia

(Modified DSM III, reference 227)

1. Loss of intellect sufficient to impair social or occupational function.

2. Memory impairment.

3. One of the following:

- impaired abstraction

— impaired judgement

- aphasia

- agnosia

- constructional difficulties

- personality change

4. Alert state of consciousness the nucleus basalis in Alzheimer's disease contrasts with Huntington's disease, where the number of basalis neurons does not seem to be reduced in demented patients. ${ }^{17.18,29}$ Significant depletion of the large neurones has recently been reported also in Parkinson's disease without concomitant Alzheimer changes. ${ }^{20.30,31}$ Both decreased $^{32}$ and normal ${ }^{33}$ numbers of cells have been reported in Pick's disease.

Ball et al ${ }^{34}$ recently reported that decline in cognitive function correlates with changes in the hippocampus with or without cortical changes.

In addition to neuronal loss in the regions noted, Alzheimer's disease is characterized by the accumulation of large numbers of neurofibrillary tangles and lipofuscin, notably in neocortex, hippocampus, basal forebrain and amygdala, senile or neuritic plaques (especially in cortex and amygdala), as well as astrocytic hyperplasia and, particularly in the hippocampus, granuo-

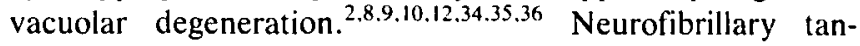
gles comprise argyophilic fibers consisting of paired helical filaments, each about $100 \AA$ wide. ${ }^{2,12.37}$ Senile plaques consist of the remnants of neuronal degeneration surrounding a dense central amyloid core. Their number seems to correlate with the severity of dementia, ${ }^{34,38.39 .40}$ whereas the amount of lipofuscin does not. ${ }^{41}$ Although the constellation of pathoiogical features is characteristic, the individual components are nonspecific and can be found in the brains of aged non-demented persons, ${ }^{9.42}$ Down's syndrome ${ }^{43}$ in various extrapyramidal syndromes including Parkinson's disease, ${ }^{44,45}$ progressive supranuclear palsy, ${ }^{46}$ parkinsonism-dementia complex of Guam, ${ }^{47}$ subacute sclerosing panencephalitis ${ }^{48}$ and dementia pugilistica. ${ }^{43,48,49,50}$

Neurochemical alterations reflect the structural changes. The loss of hippocampal and cortical cholinergic neurons and of cholinergic axons ascending from the nucleus basalis of Meynert, lead to significant declines in acetycholine and the activity of cholinergic enzymes (choline acetyltransferase and acetycholinesterase); changes in other neurotransmitters are less profound. $51.52,53.54 .55 .56 .57 .58 .59$ Muscarinic acetycholine receptors are normal. $58,60,61,62$

Indices of noradrenaline, dopamine and serotonin may be decreased in cerebral cortex and hippocampal noradrenaline, dopa-

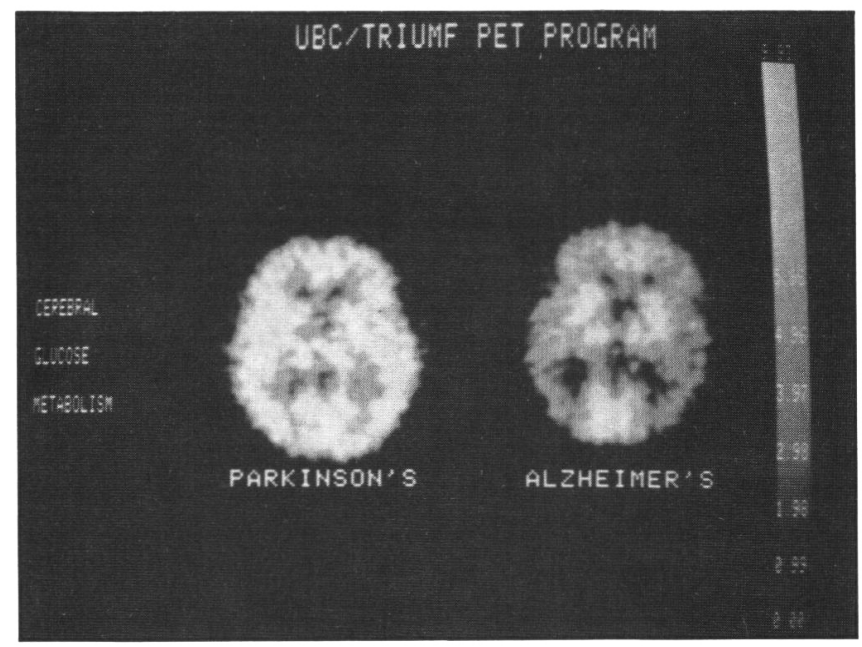

Figure 1 - Fluorodeoxyglucose (FDG)PET scans of patients with Parkinson's disease and Alzheimer's disease. The Parkinson scan is normal (see figure 2 for comparison) but in the Alzheimer scan, there is hypometabolism in temporoparietal cortex, with preservation of subcortical structures and occipital cortex. 
mine and serotonin activity is diminished. ${ }^{26.27 .56,63.64,65,66,67}$ There is a loss of noradrenergic and serotonergic projections from the brain stem, particularly the locus ceruleus. ${ }^{25,27.63 .68}$ Comparable changes have also been reported in the hypothalamic nuclei and caudate ${ }^{26.65,69}$ in postmortem material. Reduced levels of striatal dopamine have also been noted ${ }^{56.57}$ but the reports have been variable, ${ }^{71}$ and striatal MAO-B activity is increased. ${ }^{56}$ Homovanillic acid concentrations are reported to be low in striatum ${ }^{72}$ and CSF. ${ }^{73,74}$ The concentration of dopaminebeta-hydroxylase is decreased in cortex and hippocampus. ${ }^{75}$ The number of striatal dopamine receptors is claimed to fall, ${ }^{76}$ particularly D2 receptors. ${ }^{62.77}$ Serotonin (S1 and S2) receptors are reduced in the cerebral cortex, hippocampus and amygdala but not in the basal ganglia or in the basal forebrain.

Somatostatin-like immunoreactivity is reduced in the cortex ${ }^{78}$ and somatostatin receptors are also decreased. ${ }^{79}$ Neuronal tangles have been demonstrated within somatostatin neurons ${ }^{80}$ and somatostatin immunoreactivity has been demonstrated within neuritic plaques. ${ }^{81}$ Significant alterations in peptide concentrations seem to be limited to somatostatin, ${ }^{78.81}$ and possibly substance $\mathrm{P}^{34,54,82,83,84}$ and the GABA system seems also to be relatively spared. ${ }^{64,82,83,85}$ Diminished GABA has been reported in the temporal cortex,${ }^{82,83}$ but this finding was not substantiated by another investigator. ${ }^{86}$

Analyses have mainly been performed on postmortem samples with the exception of the work of Francis et al, ${ }^{87}$ who reported a correlation between reduced acetylcholine synthesis measured in vivo (in cortical biopsy samples) and cognitive function. There were less significant changes in serotonin, noradrenaline and 5-HIAA. Furthermore, the Alzheimer biochemistry may be different in early onset disease compared to late. These various neurotransmitter alterations are likely to reflect neuronal loss and their significance in clinical dementia remains to be shown. Perhaps further insight will emerge by taking heterogeneity into account. For example, Mayeux et al ${ }^{88}$ divided patients into subgroups: 1. Benign with no or little progression, 2. myoclonic with severe intellectual decline, 3. extrapyramidal with severe intellectual and functional decline, 4. typical.

The most important symptom in the Alzheimer's disease is the relentless decline in intellectual functions, that occurs much more rapidly than during normal aging. Short of brain biopsy, there is no specific test available for diagnosis during life so other dementing diseases (Table 1) must be excluded. One usable set of criteria is given in Table $3{ }^{89}$ The first symptom of the disease is almost always a decline in memory with impaired ability to learn new and recall old information.

The general physical and neurological examination is unremarkable at early phases of the illness, contrasting clearly with the abnormal neurological findings related to movement disorders which may or may not be accompanied by a decline in mental functions (Table 4). With more advanced disease, the dementia may frequently be accompanied by extrapyramidal signs comparable to parkinsonism: hypokinesia, rigidity, postural changes and tremor. ${ }^{90}$ These may be associated with primitive reflexes, myoclonus, seizures and incontinence. There seem to be atypical cases of Alzheimer's disease combined with pyramidal and extrapyramidal signs early in the illness. ${ }^{91}$

\section{Huntington's Disease}

Huntington's disease $\mathrm{e}^{92,93,94}$ is characterized by chorea, dementia and a history of similar symptoms in relatives, the mode of inheritance being autosomal dominant. The adult type has its onset between 30 and 40 years of age. Both the earlier age of onset and the clinical features distinguish Huntington's disease from Alzheimer's disease. Involuntary movements usually begin at about the same time as patients begin to experience difficulties in their memory function. Early in the disease the choreic movements may be intermittent and localized but they later become generalized, involving facies, head, trunk and legs. Dystonic postures are evident in advanced cases and the end stage of the disease is characterized by fixed flexed posture. A few subjects may have pyramidal signs and some may have disturbed oculomotor function. ${ }^{93.95 .96,97.98}$ Close to $15 \%$ of the patients have the rigid (Westphal) variant of the disease. ${ }^{99.100}$ This often begins in the second decade and is frequently accompanied by grand mal epilepsy. ${ }^{101,102}$ Cases with the Westphal variant at an older age could be confused with parkinsonism.

Unlike idiopathic Parkinson's disease, the memory decline in Huntington's disease is usually evident early and personality

\section{Table 3. Criteria for clinical diagnosis of Alzheimer's disease (Modified from reference 89)}

Probable

Dementia established by clinical evaluation and verified by neuropsychological examination.

Deficits in at least two cognitive areas.

Progressive worsening of memory and other cognitive functions over a period of months.

Alert state of consciousness.

Onset between ages of 40 and 90 years.

Absence of systemic disorders that could account for progressive deterioration of intellectual function.

Diagnosis is supported by progressive deterioration of specific cognitive functions such as language (aphasia), motor skills (apraxia), and perception (agnosia), impaired activities in daily living and altered behaviour, normal cerebrospinal fluid, normal or nonspecific changes in EEG and CT evidence of cerebral atrophy.

Definite

Clinical criteria for probable Alzheimer's disease fulfilled.

Histopathological evidence obtained from biopsy or autopsy.

Table 4. Clinical characteristics of primary degenerative dementias (Modified from reference 220)

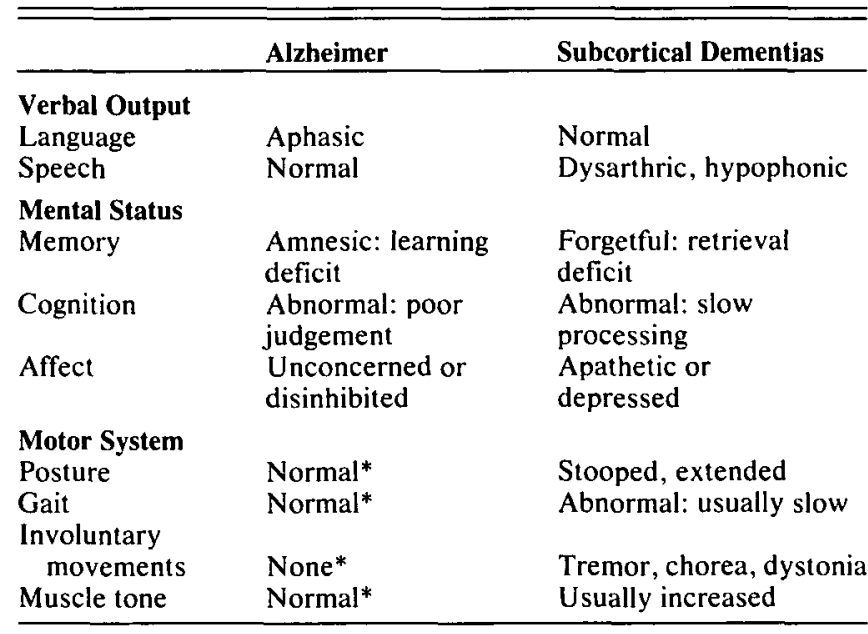

*Non-specific abnormalities in late stages of the disease. 
changes, such as apathy, anxiety, irritability, impaired concentration and bizarre behaviour ${ }^{103}$ are frequent and often profound. About $50 \%$ of the Huntington patients show significant depression, sometimes alternating with mania, ${ }^{104,105,106.107}$ and about $25 \%$ have psychotic symptomatology resembling schizophrenia. ${ }^{106.107,108}$ Unlike the depression of Parkinson's disease, that of Huntington's disease often conforms to the DSM-III criteria for major depression with frequent suicides. ${ }^{104,108} \mathrm{Per}$ sonality changes and psychiatric symptoms are usually present in the early stages of the disease; in about one third of subjects they precede the chorea. $109,110,111,112$

The profile of dementia in Huntington's disease seems to differ from that in Alzheimer's disease: the verbal linguistic abilities are relatively spared, with no aphasia or agnosia in Huntington's disease, and short term memory is significantly more severely affected than long-term memory. In contrast, intellectual decline in Alzheimer's disease is characterized by early impairment of language, prominent loss of long term memory with relative preservation of immediate recall in many early cases. ${ }^{113,114.115,116.117 .118 .119}$ Later, more global intellectual disintegration occurs. ${ }^{120}$

Extensive degeneration of the caudate nucleus is the pathological hallmark of advanced cases of Huntington's disease but caudate atrophy also occurs in other choreatic diseases. ${ }^{1 / 8,121,122,123}$ Loss of neurons also occurs in the putamen ${ }^{8.124 .125}$ and thalamus; ${ }^{126,127}$ the ventroanterior putamen is relatively spared. ${ }^{128}$ Macroscopic changes include slight to moderate subcorticalfronto-parietal brain atrophy rather than cortical atrophy. The most significant microscopic change is preferential loss of small neurons both in striatum and thalamus; the large neurons may be selectively spared in the rigid variant. ${ }^{129}$ Neurons are lost in the cerebral cortex and hippocampus. ${ }^{8,124,130}$ Unlike Alzheimer's disease, there is no significant decrease in the number of cholinergic neurons in the nucleus basalis of Meynert. ${ }^{17.18 .29}$

Profound declines of GABA and its biosynthetic enzyme glutamic acid decarboxylase take place in both striatum and substantia nigra. ${ }^{131.132 .133 .134 .135 .136,137}$ The CSF GABA content may be reduced. ${ }^{138.139 .140}$ The number of GABA receptors is decreased in putamen and caudate but increased in substantia nigra. ${ }^{141}$ Significant depletion of acetylcholine transferase occurs, ${ }^{132,143,142,143}$ while monoamine oxidase and tyrosine hydroxylase levels are normal. ${ }^{142}$ Changes in dopamine are controversial. Spokes ${ }^{144}$ observed significant increases in dopamine in striatal nuclei, nucleus accumbens and substantia nigra pars compacta. Birds and Iversen ${ }^{134}$ found increased putamenal dopamine in rigid patients but most of these were advanced cases, rather than juvenile forms. Melamed et al ${ }^{145}$ reported normal levels of dopamine in the caudate nucleus and an increase in putamen, but the HVA-dopamine ratio was unchanged.

Changes in morphology and biochemistry of the cerebral cortex are less than those in the subcortical structures. ${ }^{\mathbf{1 4 2 . 1 4 3}}$ These differences are reflected in the pattern of glucose utilization, which is decreased more in the striatum than in cortical areas. ${ }^{146.147}$ We have found decreased cortical glucose metabolism in the cortex of patients with Huntington's disease, ${ }^{148}$ particularly in the frontal lobes, which are relatively spared in Alzheimer's disease. Others have reported ${ }^{149}$ decreased coupling between various cortical regions in Huntington's disease.

In Huntington's disease there is a significant increase in somatostatin ${ }^{150}$ and a loss of substance $\mathrm{P}$, met-enkephalin and cholecystokinin. ${ }^{151,152,153}$ The activity of the peptide metabo- lizing enzyme proline endopeptidase activity is abnormally low in striatal nuclei. ${ }^{154}$ The number of somatostatin containing neurons seems to be decreased in striatum but not in the substantia nigra. ${ }^{155}$

\section{Parkinson's disease}

Parkinsonism has many possible causes (Table 4). We will focus on idiopathic parkinsonism or Parkinson's disease, with emphasis on memory and cognitive functions, comparing these with Alzheimer's disease and Huntington's disease.

Parkinsonism is a motor disorder, characterized by a stooped posture, relative immobility, and tremor at rest. Speech may be monotonous and the voice may lose its volume. A slow gait with short steps is associated with loss of normal arm swings; progression is interrupted by brief periods of 'freezing', and there may be difficulty in negotiating doorways, turning, and maintaining balance. Rigidity is elicited during examination of passive movements but there are no pyramidal signs and sensory examination is normal (even though sensory symptoms varying from paresthesiae to pain may occur). Parkinson's disease is not solely a disorder of motor system, however; autonomic and higher mental functions are also involved. Autonomic symptoms include constipation and urinary retention. Parkinson's disease is some 20 times more common than Huntington's chorea. The disease is sporadic in most cases, with increasing frequency after the age of $\mathbf{4 0}$ years, although juvenile forms exist $^{156}$ and there are occasional hereditary forms. ${ }^{157}$ Unlike Alzheimer's disease and Huntington's disease, regional glucose utilization (Figure 1) is not grossly disturbed, ${ }^{158}$ although interregional metabolic relationships may be altered. ${ }^{149.159}$

Recently it has been recognized that cognitive decline occurs in idiopathic Parkinson's disease though this feature was either neglected or even denied in some earlier studies. The estimated frequency of cognitive decline varies widely. Clinical studies without formal psychological examination in 1354 unselected patients with Parkinson's disease have led to estimates of dementia in 8 to $56 \%$ of patients. ${ }^{45,160,161,162,163.164,165.166}$

The most extensive of the above surveys included a total of 964 patients and it was concluded that the prevalence of demen-

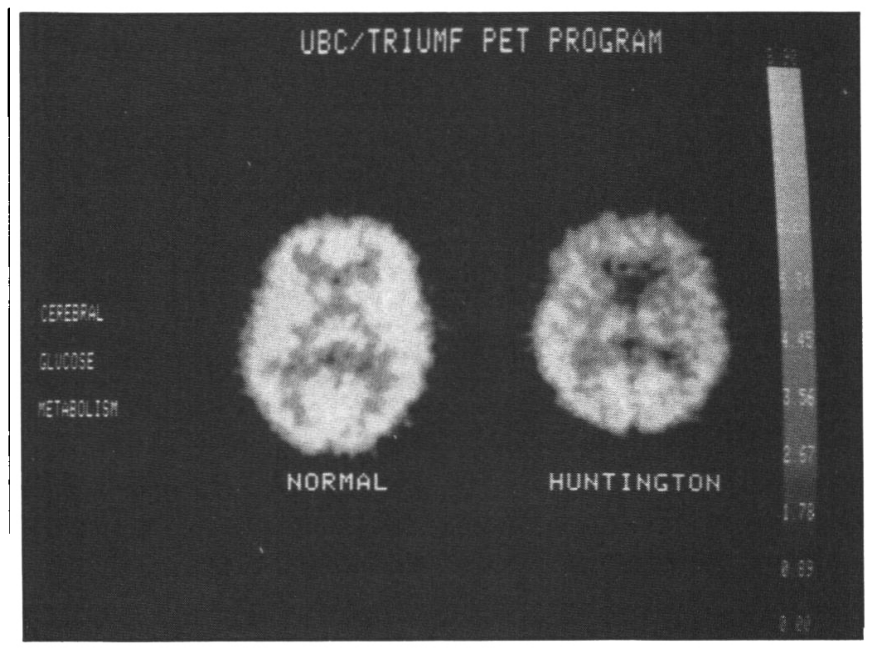

Figure 2 - FDG PET scan of a patient with early Huntington's disease, who had normal caudate nuclei as assessed by $C T$. There is obvious hypometabolism in the caudates compared to a normal scan at the same level, as well as a decrease in cortical metabolism, particularly in the frontal lobes. 
tia was $29-32 \% .^{106.107 .163}$ It seems probable that the prevalence of dementia at the time of diagnosis of Parkinson's disease is higher (about 10\%) than in the normal population of comparable age. $^{167}$

Studies employing formal psychological tests report cognitive declines between $3 \%{ }^{168}$ and $93 \%{ }^{169}$ of patients (Table 5). It is difficult to compare the results (Table 5) since patients had varied durations of disease, were on varying medications and some had undergone stereotactic surgery. It is also possible that earlier literature included patients with Shy-Drager syndrome and Steele-Richardson-Olszewski syndrome prior to their general recognition as separate entities.

In spite of the wide range of observations, it is certain that dementia is a significant cause of disability in Parkinson's disease, and dementia is more common in patients with more severe motor deficits; ${ }^{170}$ cognitive function and memory declines as the disease advances. ${ }^{171,17 / \mathrm{a}}$ However, the extent of dementia in various phases of the illness is still controversial, ${ }^{172,173}$ and its profile is only now being characterized. ${ }^{173 a}$ Declines have been reported to occur in memory, concept formation, solving of complex problems, visuospatial processing and perceptual motor function. Information processing is slow, but there is generally no aphasia or agnosia. Depression is common (about $50 \%$ ), and reported to be more frequent in subjects with cognitive impairment. ${ }^{174}$

One of the most confounding aspects of evaluating the dementia in Parkinson's disease is assessing the impact of medications (Table 5). It is well known that anticholinergic agents and dopaminomimetics can have adverse mental effects, including confusion and psychosis. It was recently reported ${ }^{175}$ that after one month of treatment with small doses of trihexyphenidyl, a mean decrease of about $30 \%$ occurred in recent recall but not in immediate memory tests; the score for associative learning decreased from 12.7 to 10.7 .

To obtain further information on the mental profile of Parkinson's disease, we analyzed the neuropsychological performance of 130 patients with Parkinson's disease (mean age 62.2 years, mean disease duration 4.7 years, mean clinical disability 3.3 on Hoehn and Yahr ${ }^{176}$ scale).

We employed subtests (similarities, picture completion and block design) of the Wechsler Adult Intelligence Scale (WAIS) and Wechsler Memory Scale (WMS-1) with digit span, logical memory, associative learning and visual reproduction subtests. The level of depression was assessed using Beck Depression Index. The subjects were tested at their first visit.

The memory scores, arranged by ascending order of performance of individual patients in each of the four tests, are shown in Figure 4. It is evident that the variation between individual patients was large. Furthermore, the number of patients with abnormally low scores was much larger in the more complex subtests (such as logical memory and associative learning) that required processing of material, than in a less demanding test (digit span) based upon immediate retrieval of numbers.

The cognitive profile (subtests of WAIS) is shown in Figure 3. Again a large range was observed in the performance of individual patients. The number of subjects with relatively good performance in the picture completion subtest was larger than in the block design or similarities subtests.

Comparison of the present results with the figures published for Alzheimer's and Huntington's disease indicates that the memory profile in our patients resembled Alzheimer's disease more than Huntington's disease.

The mean Beck Depression Index (+SD) was $5.18(+4.9)$ and the depression scores of individual patients are shown in Figure 5 . In some $50 \%$ of the patients the score was 5 or more, indicating some degree of depression. There was a small group of patients $(8 \%)$ who could be considered to be significantly depressed, although only two fulfilled the DSM III criteria for major depression. The subjects with more significant depression might differ from the general parkinsonian population who showed relatively linear and gradual increases of the Beck index (Figure 3). It seems evident that the level of depression in Parkinson's disease is only rarely comparable to that seen in Huntington patients, and may be more comparable to the depression that occurs in Alzheimer's disease.

Toevaluate the memory and cognitive performance of patients free from drug effects and to compare their performance with normal controls, we analyzed 67 patients who had not received any antiparkinson medications, and 43 control subjects (mean age 59.4 years). The mean age of the patients was 59.1 years and mean disability ${ }^{176}$ was 2.3 . None of the subjects had other

Table 5. Psychological studies evaluating cognitive performance in Parkinson's disease

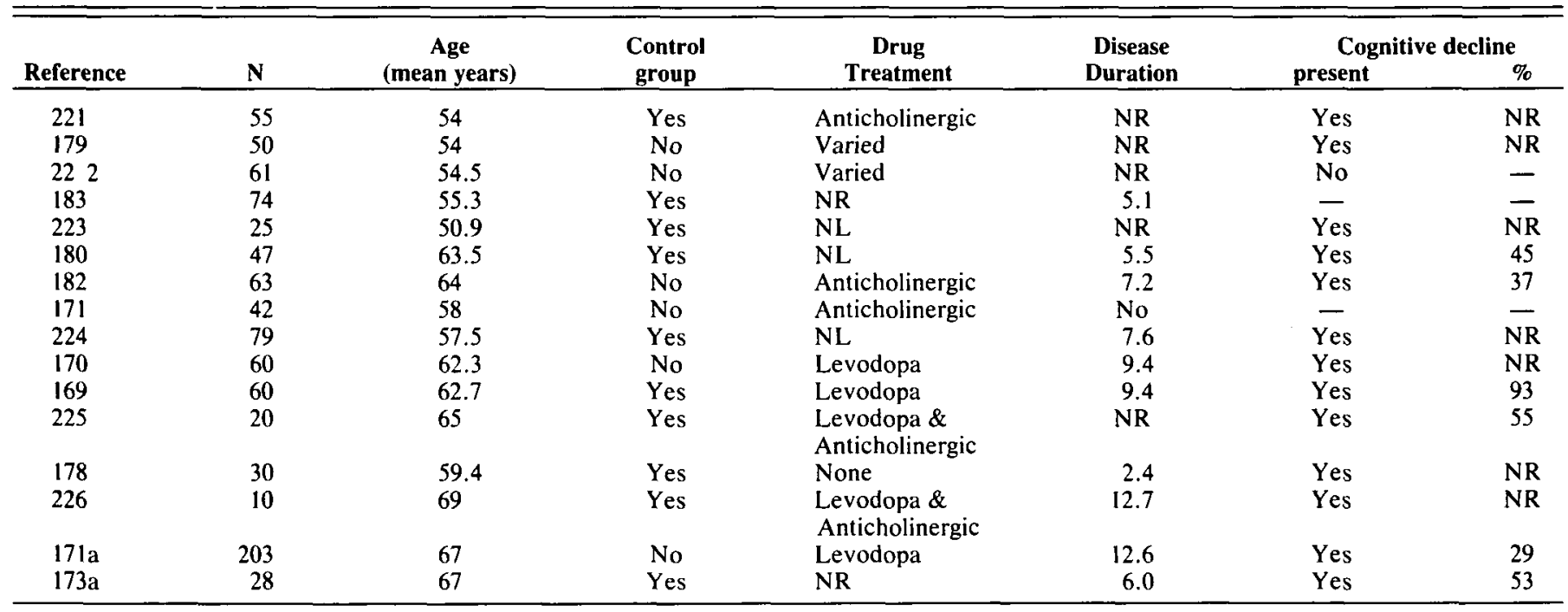

$\mathrm{NR}=$ not reported

$\mathrm{NL}=$ no levodopa, other treatment not reported 
neurological diseases. The patients and the controls received the same test battery as already described. The data were submitted to statistical analysis using Chi-square test, Student's t-test, Pearson's product-moment correlation, canonical correlation and discriminant analysis. The clinical neurological disability (Columbia score) and the psychometric performance of the two groups is shown in Table 6 and Figure 6 . The patients scored lower than the controls in all the memory tests except the digit span subtest, confirming the less rigorously obtained data from the general population shown in Figure 4. The cogni-

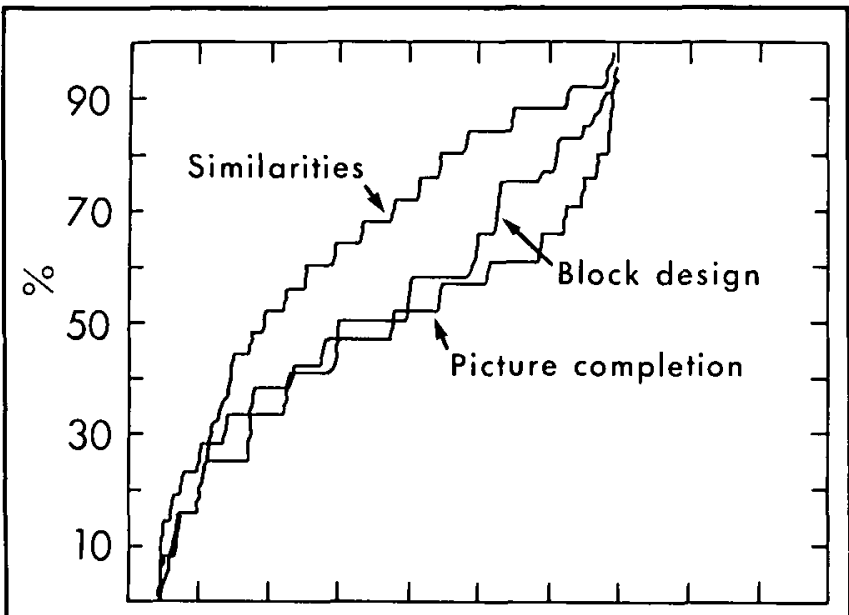

Figure 3 - Subcores for cognitive (WAIS) tests in 140 unselected patients with Parkinson's disease at their first visit expressed as percent of maximum obtainable score and arranged in ascending order. The cognitive score obtained by individual patients show large variations as did the memory score (Fig. 4). The number similarities of patients with relatively good performance in the subtest was larger than in the subtests of block design and picture completion: 75 patients out of 140 scored less than $50 \%$ of maximum possible in the picture completion and 59 in the block design test compared with 38 patients in the subtest of similarities.

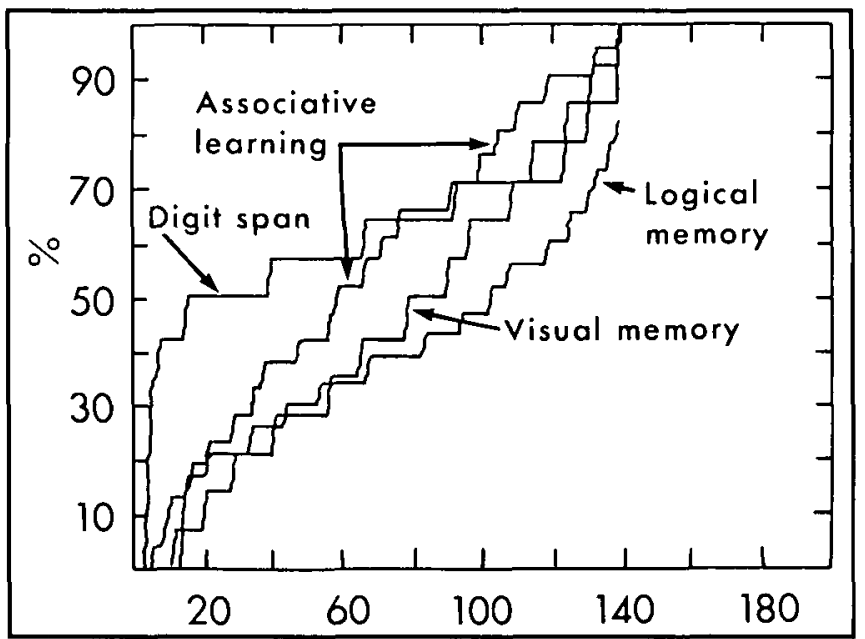

Figure 4 - Subscores of WMS-I memory texts obtained in 130 unselected patients with Parkinson's disease at their fist visit. The scores are expressed as per cent of maximum possible score for the test in ascending order of performance. The number of patients with low scores is much larger in more complex subtests requiring processing of material, than in the digit span subtests which only required immediate retrieval. Out of the 140 patients, 102 patients scored less than $50 \%$ of the maximum possible in the test for logical memory, as did 78 in the test for visual memory, 58 in the test for associative learning and less than 15 in the digit span test. tive performance of the patients was inferior to the controls only in the block design subtest of WAIS, which necessitates the use of both motor capabilities and visuospatial abilities. Critical flicker fusion frequency was analyzed since the test is said to correlate with the level of attention; ${ }^{177}$ the results in the two groups were not significantly different.

Examination of untreated patients allowed a unique possibility to evaluate the relationships between mental function and motor disability. There was no significant association between the Columbia score or its subscores and either cognitive function or memory; the correlation coefficients are shown in Table 7. The results were verified by canonical correlation analysis. Lees and Smith ${ }^{178}$ reported difficulties in shifting conceptual sets and perseverative errors in a group of untreated parkinsonian patients, whereas there was no significant memory decline. Their patients were somewhat less disabled but perhaps of greater importance, they used a memory test (two choice recognition test) that measured recognition mainly. Our results also indicated that immediate retrieval was not significantly inferior to the performance of the controls whereas more complex subtests involving mental processing showed a small but definite impairment.

This mean Beck Depression Index was somewhat higher in these untreated patients than in the general parkinsonian population (5.9); it did not correlate with neurological disability or with the memory or cognitive scores. A possibility thus exists that the depression, cognitive decline and the motor disability are separate biological phenomena in Parkinson's disease even if they often occur together. Impaired cognitive functions have previously been reported to be associated with rigidity, ${ }^{163,179}$ akinesia, ${ }^{180}$ bradykinesia, ${ }^{163.170 .181}$ all of these ${ }^{182}$ or none of

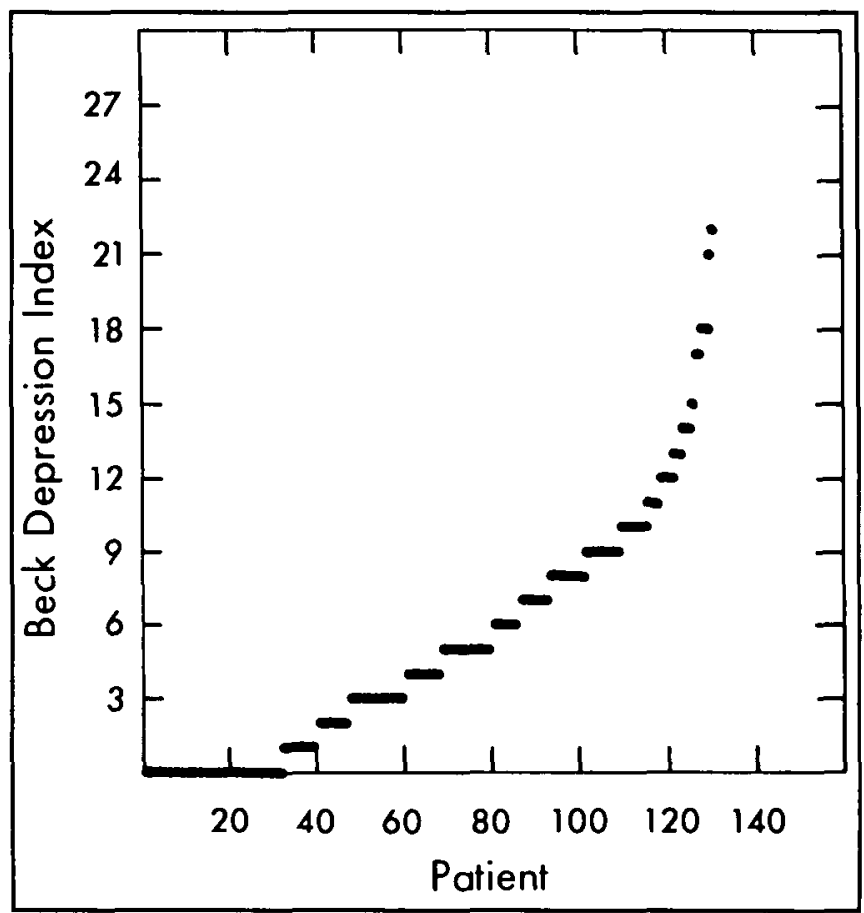

Figure 5 - Beck Depression Index (BDI) of 130 unselected patients with Parkinson's disease at their first visit arranged in ascending order. The mean $B D I$ was 5.18 indicating that about $50 \%$ of the patients were at least mildly depressed. The BDI was less than 12 in about 120 patients; only w' patients obtained BDI scores comparable to those observed in major depressions. 
these. ${ }^{183}$ Some of the discrepancies may be explained by the drug therapy used in the previous studies, which may have had significant effects on the clinical scores. In addition, larger studies have included a more severely disabled population of patients.

By dividing the untreated parkinsonian subjects arbitrarily into two groups, over 60 years (mean 67.2 ) and 60 years or younger (mean 49.1), it was possible to study the relative effect of aging on cognitive functions in a population of patients with
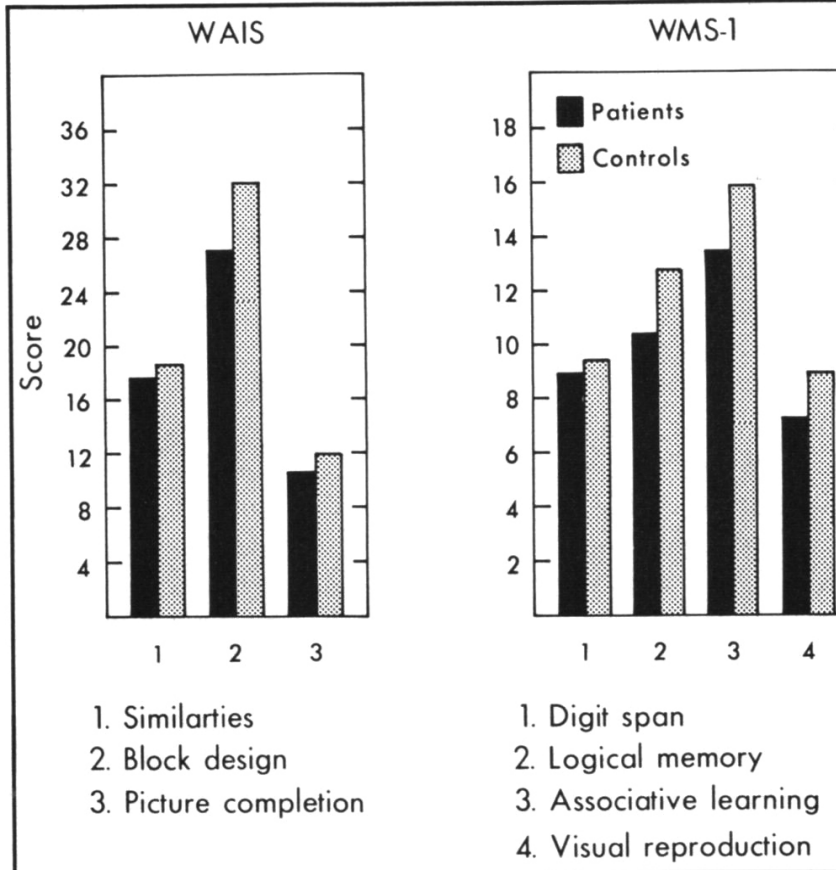

Figure 6-Mean scores of cognitive (WAIS) and memory (WMSI) performance in 67 untreated patients with Parkinson's disease (solid bars) and 43 age-matched controls (dotted bars). The patients performed worse than the controls in the WAIS similarities (1), block design (2) and picture completion (3) subtests. This difference had statistical significance $(p<0.05)$ only in the block design subtest (2). The inferior memory performance (WMSI) of the patients compared to the control subjects reached statistical significance in the subtests of logical memory $(2, p<0.01)$, associative learning $(3, p<0.01)$ and visual memory $(4, p<0.05)$ but not in the digit $\operatorname{span}(1, p>0.05)$ similar clinical disability. (Columbia total score for 'young' = 20.0 - 9.1 and 'old' 24.2 - 9.7). An age-related decrease of about $15 \%$ in psychomotor and cognitive performance occurred between ages 50 and 70 related to aging (Figure 7) except for logical memory, which did not decline.

From our observations (Figures 3 and 4), some $20 \%$ of the total population of parkinsonian patients studied obtained a score less than $30 \%$ of maximum possible on formal psychological examination, indicating impairment of memory and cogni-

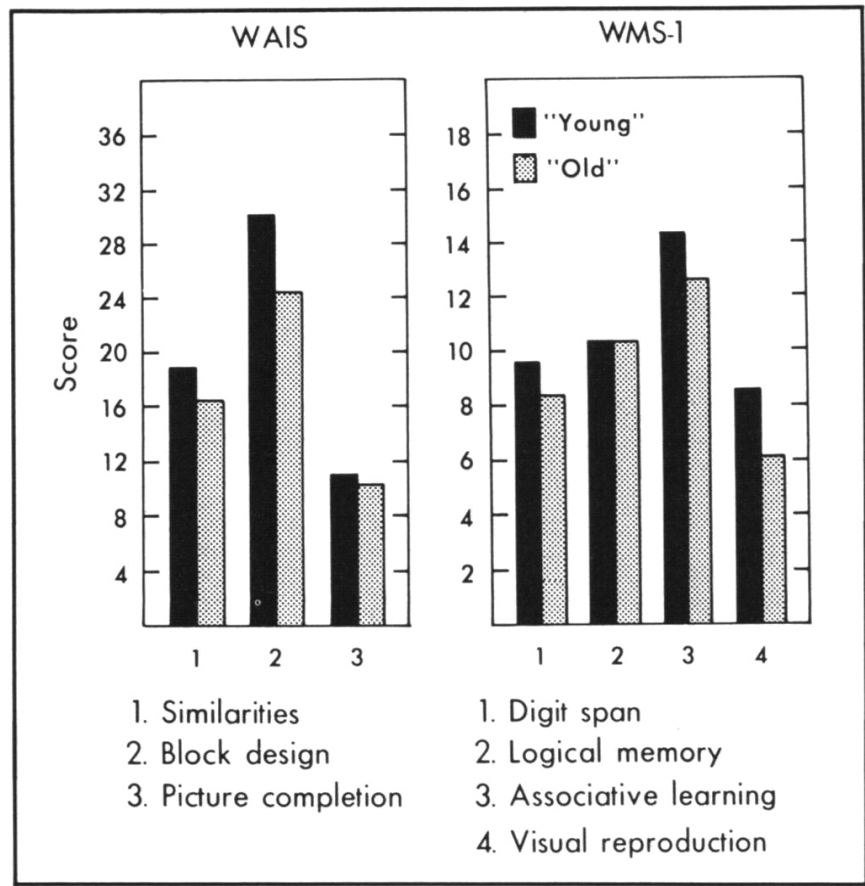

Figure 7 - Mean cognitive (WAIS) and memory (WMSI) scores of untreated patients with Parkinson's disease less than $60(49.1+7.0$, mean $+S D$ $N=30)$ and 60 or more $(67.2+6.1$, mean $+S D, N=37)$ years of age. The older patients (donted bars) performed worse than the younger (solid bars) in the WAIS similarities (1) and block design (2) subtests, but the difference was small in the picture completion (3) subtest. There was no difference in the WMSI logical memory (2) subtests whereas the performance of the older patients was inferior to that of the younger ones in the WMSI subtests of the digit span (1), associative learning (3) and visual memory (4).

Table 6. Cognitive and memory functions in untreated Parkinsonian patients and controls (mean + SD)

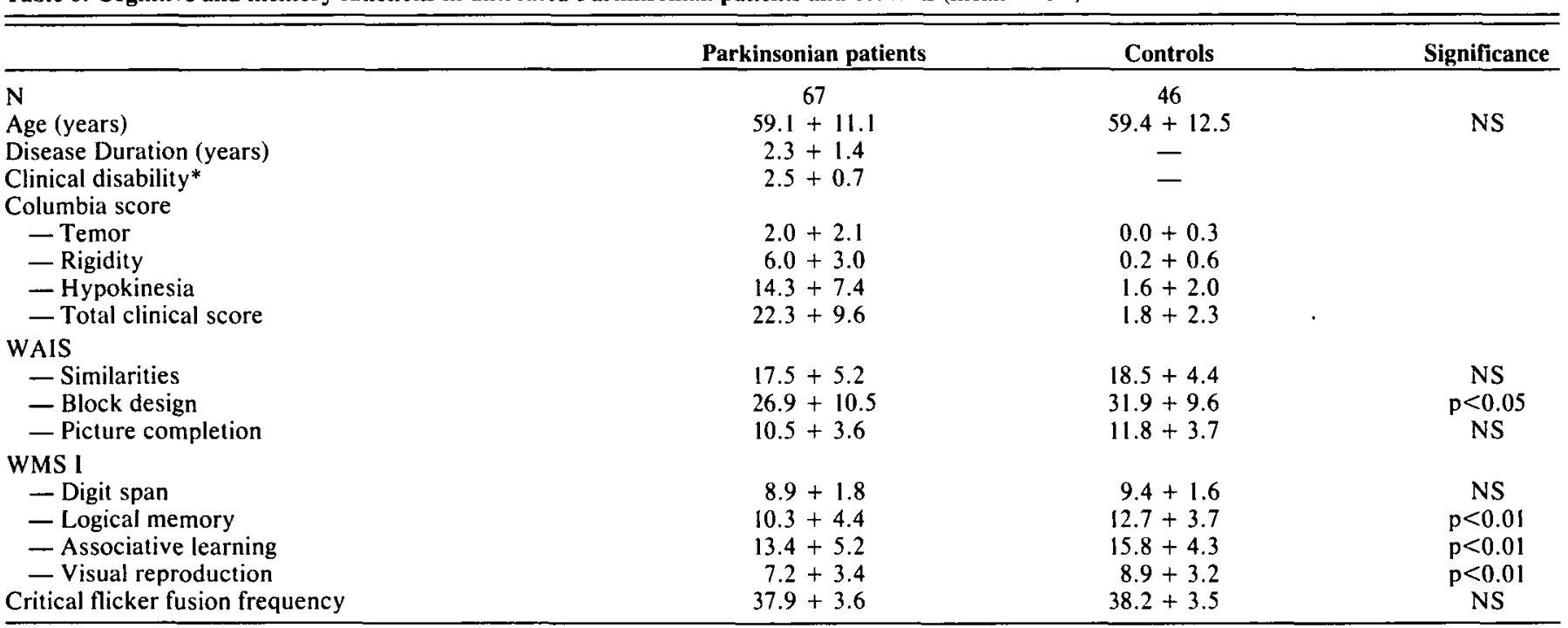


tive ability. These findings do not emerge in the early years of disease. The patients with Parkinson's disease differ from those with Alzheimer's disease in that their memory loss is relatively small in comparison with the control population and they do not seem to have a sufficient variety of other cognitive deficits to justify the term dementia.

Diffuse cerebral atrophy is commonly observed in neuroradiological and post mortem studies of Parkinson's disease, ${ }^{184,185.186}$ but the striatal changes are usually slight, ${ }^{187}$ in contrast to Huntington's disease. Similarly, minor changes are frequently present in hippocampus, ventral tegmental, and hypothalamic nuclei. ${ }^{188.189}$ Histological changes are characterized by profound degeneration in the substantia nigra pars compacta. Significant but less severe loss of neurons is found in other catecholamine containing nuclei, such as locus ceruleus, and dorsal vagal nucleus. ${ }^{190.191}$ The presence of Lewy bodies may be found in the involved structures.

Alzheimer-type neuropathological changes, such as neurofibrillary tangles and senile plaques, are present to variable degrees in Parkinson's disease but their significance is controversial. The severity of the motor deficits correlates with the neuronal loss in the substantia nigra, ${ }^{44}$ but the reported association of parkinsonian dementia with Alzheimer-type changes in the neocorte ${ }^{45.192}$ is far from established. Hakim and Mathieson ${ }^{165}$ observed more Alzheimer changes in parkinsonian brains than controls but more recent studies indicate that the number of neuritic plaques and neurofibrillary tangles in Parkinson's disease may not be significantly different in patients with or without dementia, nor do their numbers differ from those observed in a normal age-matched population. ${ }^{193.194}$ Furthermore, dementia may exist in parkinsonian patients without concomitant Alzheimer neuropathology. ${ }^{195.196,197}$ The evidence does not allow any firm conclusion on whether cognitive decline is related to decreased neurons in the nucleus basalis of Meynert. In one report, loss of these neurons was seen in demented parkinsonian patients whereas no change was observed in patients without dementia. ${ }^{198}$ In contrast, Candy et al ${ }^{199}$ reported significant reduction of the neurons in the nucleus basalis without Alzheimer neuropathology in three parkinsonian patients without dementia; this clinicopathological finding may be more frequent than previously recognized. ${ }^{31}$

Neurochemical studies have given more consistent results relating to catecholamine pathways than cholinergic systems. Profound decreases in striatal dopamine have been observed with significant but less marked reductions in the hippocampal and limbic regions, ${ }^{200,201,202}$ and others $\mathrm{cf},{ }^{203,204}$ Depletion of

Table 7. Correlations of cognitive and memory functions with extrapyramidal symptoms (Columbia score) in untreated Parkinsonian patients

\begin{tabular}{lcccc}
\hline \hline & & & & \\
& Tremor & Rigidity & Hypokinesia & $\begin{array}{c}\text { Total } \\
\text { Score }\end{array}$ \\
\hline WAIS & & & & \\
— Similarities & 0.23 & 0.01 & 0.08 & 0.02 \\
- Block design & 0.05 & 0.13 & 0.10 & 0.13 \\
- Picture completion & 0.11 & 0.04 & 0.13 & 0.11 \\
WMS I & & & & \\
- Digit span & 0.20 & 0.05 & 0.02 & 0.05 \\
- Logical memory & 0.10 & 0.07 & 0.03 & 0.01 \\
- Associative learning & 0.04 & 0.04 & 0.00 & 0.00 \\
- Visual reproduction & 0.01 & 0.03 & 0.09 & 0.06 \\
\hline
\end{tabular}

serotonin and noradrenaline occurs in the basal ganglia, limbic system and neocortical areas, in accord with the histological findings. ${ }^{137.202 .205 .206 .207}$ While dopamine is thought to play a crucial role in motor function, decreases in serotonin may be related to depression. ${ }^{208}$

A plausable concept of cholinergic dysfunction has not yet emerged and its relationship to memory and cognitive decline in parkinsonism remains to be elucidated. There are reports that nondemented patients with parkinsonism may have normal choline acetyltransferase activity (CAT) in the cortex, ${ }^{30.196}$ but subnormal CAT activity has equally been claimed to occur in parkinsonian patients whether or not they were demented. ${ }^{209}$ A recent study ${ }^{59}$ reported a high degree of correlation between mental impairment and reduction in temporal neocortical CAT activity. These changes were correlated with cell counts in the nucleus basalis, but not with plaque or tangle formation. Also reminiscent of Alzheimer's disease is the observation of Epelbaum et $a^{210}$ that hippocampal somatostatin is decreased in demented parkinsonians.

Finally, Kuhl et al ${ }^{158.211}$ found severe temporoparietal hypometabolism in PET studies on demented subjects with Parkinson's disease, the pattern usually associated with Alzheimer's disease. More studies combining clinical, neuropsychological, histopathological and biochemical observations are needed, taking into account that there are subgroups in Parkinson's disease ${ }^{170.212}$ as in Alzheimer's disease, ${ }^{213.88}$ and that combinations of both diseases must exist.

\section{Other movement disorders}

In progressive supranuclear palsy, ${ }^{46}$ conjugate gaze palsy, facial spasticity, pseudobulbar palsy and parkinsonian features are frequently associated with dementia. ${ }^{214.215}$ Neuronal loss, neurofibrillary tangles and plaques affect nuclei of the striatum, brainstem and cerebellum. Glucose hypometabolism in prefrontal cortex has recently been reported, ${ }^{216}$ and the authors considered that this might reflect disturbed innominatocortical projections. There is indeed loss of large cells of the nucleus basalis in this disorder. ${ }^{217}$

Striatonigral degeneration ${ }^{218}$ may be clinically indistinguishable from Parkinson's disease. Mild cognitive changes may occur, but these are poorly characterized and brain biochemistry has not been studied. Nevertheless, a subcortical basis for the clinical features is probable, because cortical pathology is minimal.

In both multiple system atrophy (Shy-Drager syndrome) and olivopontocerebellar atrophy, dementia can occur in combination with bradykinesia, rigidity, tremor, ataxia or autonomic dysfunction.

The combination of rapidly progressive dementia, parkinsonism, ataxia and myocionus is suggestive of CreutzfeldtJakob disease.

Corticodentatonigral degeneration ${ }^{219}$ is a rare disorder characterized by hypertonia, involuntary movements and a profound degree of apraxia. The characteristic pathological feature is the presence of neuronal achromasia with neuronal degeneration affecting the cerebral cortex, substantia nigra and dentatoolivothalmic system. Although dementia was not a prominent feature in the original report, we have seen patients in whom the characteristic clinical features (pathologically unverified) have been associated with varying degrees of dementia and aphasia. 
Finally, dementia can occur in conjunction with dystonia and/or tremor in a variety of uncommon degenerative disorders, including Wilson's disease, Hallervorden-Spatz disease and various lipid and ganglioside storage diseases.

\section{CONClusion}

We have compared the dementia of Alzheimer's disease with various extrapyramidal disorders in which there is a deterioration in intellectual function, in particular Huntington's disease and Parkinson's disease. In contrast to Alzheimer's disease, Huntington's disease is characterized by substantial impairment of memory at a stage when dysphasia is not evident. In Parkinson's disease the prevalence and nature of dementia are controversial. Studies are generally complicated by pharmacotherapy. From our own observations we conclude that dementia occurs in $15-20 \%$ of patients, the rate being lower in early disease and higher as motor deficits become substantial. The early pattern of parkinsonian intellectual difficulty involves mental processing rather than memory, and in contrast to Alzheimer's disease, dysphasia is not prominent. In both Huntington's disease and Parkinson's disease the predominant morphological and biochemical pathology are concentrated in the striatum, and in both of these disorders there is no conclusive evidence of major changes in the nucleus basalis. These features are all distinct from Alzheimer's disease, where deterioration in memory is associated with dysphasia, and the main pathology involves the cerebral cortex and substantia innominata.

\section{ACKNOWLEDGEMENT}

We wish to thank the Dystonia Medical Research Foundation and the MRC of Canada for supporting this work.

\section{REFERENCES}

1. Alzheimer A. Uber eine eigenartige Erkrankungen der Hirnrinde. Allg Z Psychiat 1907; 64: 146-148.

2. Terry R, Katzman R. Senile dementia of the Alzheimer type: Defining a disease. In: Katzman R, Terry RD (Eds.), Neurology of Aging. Vol 22. Philadelphia, Davis 1983; pp. 51-84.

3. Roth M. Diagnosis of senile and related forms of dementia. Aging 1978; 7: 71-85

4. Shefer VF. Absolute number of neurons and thickness of the cerebral cortex during aging, senile and vascular dementia, and Pick's and Alzheimer's diseases. Neurosci Behav Physiol 1973; 6: 319-324.

5. Wood PL, Elienne P, Lal S, Nair NPV, Finlayson MH, Gauthier $S$, Palo J, Haltia M, Paetau A, Bird ED. A post-mortem comparison of the cholinergic system in Alzheimer's disease and Pick's disease. J Neurol Sci 1983; 62: 211-217.

6. Jervis GA. Alzheimer's disease. Psychiatr Q 1937; 11: 5-18.

7. McMenemy WH. Alzheimer's disease. J Neurol Psychiatry 1940; 3: $211-240$.

8. Corsellis JAN. Ageing and the dementias. In: Blackwood W, Corsellis JAN (Eds.), Greenfield's Neuropathology. Chicago: Year Book Medical Publishers 1976; pp. 796-848.

9. Tomlinson BE. The pathology of dementia. In: Wells CE (Ed.), Dementia. 2nd ed. Philadelphia: FA Davis, 1977; pp. 113-153.

10. Terry RD, Peck A, DeTeresa R, Schechter R, Horoupian DS. Some morphometric aspects of the brain in senile dementia of the Alzheimer type. Ann Neurol 1981; 10: 184-192.

11. Mountjoy CQ, Roth M, Evans NJR, Evans HM. Cortical neuronal counts in normal elderly controls and demented patients. Neurobiol Aging 1983; 4: 1-11.

12. Terry RD, Davies P. Dementia of the Alzheimer type. Ann Rev Neurosc 1980; 3: 77-95.

13. Foster NL, Chase TN, Fedio P, Patronas NJ, Brooks RA, Di Chiro G. Alzheimer's disease: Focal cortical changes shown by positron emission tomography. Neurology (Cleveland) 1983; 33: 961-965.

14. Foster NL, Chase TN, Mansi L, Brooks R, Fedio P, Patronas NJ, Di Chiro G. Cortical abnormalities in Alzheimer's disease. Ann Neurol 1984; 16: 649-645.
15. Friedland RP, Budinger TF, Ganz E. Regional cerebral metabolic alterations in dementia of the Alzheimer type: positron emission tomography with 18F fluorodeoxyglucose. J. Comput Assist Tomogr 1983; 7 : 590-598.

16. McGeer PL, Kamo H, Harrop R, et al. Positron emission imaging in patients with clinically diagnosed Alzheimer's disease. Can Med Assoc J 1986; 134: 597-607.

17. Whitehouse PJ, Price DL, Clark AW, Coyle JT, DeLong MR. Alzheimer's disease: evidence for selective loss of cholinergic neurons in the nucleus basalis. Ann Neurol 1981; 10: 122-126.

18. Whitehouse PJ, Price DL, Struble RG, Clark AW, Coyle JT, DeLong MR. Alzheimer's disease and senile dementia: loss of neurons in the basal forebrain. Science 1982; 215: 1237-1239.

19. Price DL, Whitehouse PJ, Struble RG. Basal forebrain cholinergic systems in Alzheimer's disease and related dementias. Neurosci comm 1982; 1: 84-92.

20. Arendt T, Bigl V, Arendt A. Tennstedt A. Loss of neurons in the nucleus basalis of Meynert in Alzheimer's disease, paralysis agitans and Korsakoff's disease. Acta Neuropathol 1983; 61: 101-108.

21. Arendt T, Bigl V, Ennstedt A, Arendt A. Neuronal loss in different parts of the nucleus basalis is related to neuritic plaque formation in cortical target areas in Alzheimer's disease. Neurosci 1985; 14: 1-14.

22. Rogers JD, Brogan D, Mirra SS. The nucleus basalis of Meynert in neurological disease: A quantitative morphological study. Ann Neurol 1985; 17: 163-170.

23. Herzog AG, Kemper TL. Amygdaloid changes in aging and dementia. Arch Neurol 1980; 37: 625-629.

24. Bondareff W, Mountjoy CQ, Roth M. Selective loss of neurones of origin of adrenergic projection to cerebral cortex (nucleus locus ceruleus) in senile dementia. Lancet 1981; i: 783-784.

25. Tomlinson BE, Irving D, Blessed G. Cell loss in the locus ceruleus in senile dementia of Alzheimer type. J Neurol Sci 1981; 49: 419-428.

26. Mann DMA, Lincoln J, Yates PO, Stamp JE, Toper S. Changes in the monoamine containing neurones of the human CNS in senile dementia. Brit J Psychiat 1980; 136: 533-541.

27. Mann DM, Yates PO, Hawkes J. The noradrenergic system in Alzheimer and multi-infarct dementias. J Neurol Neurosurg Psychiatry 1982; 45: 113-119.

28. Saper CB, German DC, White III CL. Neuronal pathology in the nucleus basalis and associated cell groups in senile dementia of the Alzheimer's type. Possible role in memory loss. Neurology 1985; 35: 1089-1095.

29. Clark AW, Parhad IM, Folstein SE, Whitehouse PJ, Hedreen JC, Price DL, Chase GA. The nucleus basalis in Huntington's disease. Neurology (Cleveland) 1983; 33: 1262-1267.

30. Dubois B, Ruberg M, Javoy-Agid F, Ploska A, Agid Y. A subcorticocortical cholinergic system is affected in Parkinson's disease. Brain Res 1983; 288: 213-218.

31. Nakano I, Hirano A. Parkinson's disease: Neuron loss in the nucleus basalis without concomitant Alzheimer's disease. Ann Neurol 1984; 15: 415-418.

32. Uhl GR, Hilt DC, Hedreen JC, Whitehouse PJ, Price DL. Pick's disease (lobar sclerosis): depletion of neurons in the nucleus basalis of Meynert. Neurology (Cleveland) 1983; 33: 1470-1473.

33. Tagliavini F, Pilleri G. Basal nucleus of Meynert. A neuropathological study in Alzheimer's disease, simple senile dementia, Pick's disease and Huntington's chorea. J Neurol Sci 1983; 62: 243-260.

34. Ball MJ, Fishman M, Hachinski V, Biume W, Fox A, Kral VA, Kirschen AJ, Fox H, Merskey H. A new definition of Alzheimer's disease: a hippocampal dementia. Lancet $1985 ; 1:$ 14-16.

35. Brun A, Gustafsson L. Limbic lobe involvement in presenile dementia. Arch Psychiat Nervenkr 1978; 226: 79-93.

36. Coyle JT, Price DL, DeLong MR. Alzheimer's disease: A disorder of cortical cholinergic innervation. Science 1983;219: 1184-1190.

37. Wisniewski HM, Narang HK, Terry RD. Neurofibrillary tangles of paired helical filaments. J Neurol Sci 1976; 27: 173-181.

38. Blessed G, Tomlinson BE, Roth $M$. The association between quantitative measurements of dementia and senile change in the cerebral grey matter of elderly subjects. Br J Psychiatry 1968; 114: $797-811$.

39. Perry EK, Tomlinson BE, Blessed G, Bergman K, Gibson PH Perry RH. Correlation of cholinergic abnormalities with senile 
plaques and mental test scores in senile dementia. $\mathrm{Br}$ Med $\mathrm{J}$ 1978; 2 : 1457-1459.

40. Wilcock GK, Esiri MM, Bowen DM, Smith CCT. Alzheimer's disease: correlation of cortical choline acetyltransferase activity with the severity of dementia and histological abnormalities. J Neurol Sci 1982; 57: 407-417.

41. Terry R, Katzman R. Senile dementia of the Alzheimer type: Defining a disease. In: Katzman R, Terry RD (Eds.), Neurology of Aging. Vol 22. Philadelphia, Davis 1983; pp. 51-84.

42. Ulrich J. Alzheimer changes in nondemented patients younger than sixty-five: possible early stages of Alzheimer's disease and senile dementia of Alzheimer type. Ann Neurol 1985; 17:273-277.

43. Wisniewski KE, Wisniewski HM, Wen GY. Occurrence of neuropathological changes and dementia of Alzheimer's disease in Down's syndrome. Ann Neurol 1985; 17: 278-282.

44. Alvord EC. The pathology of Parkinsonism. Part II. An interpretation with special reference to other changes in the aging brain. In: McDovell FC, Markham CH (Eds.) Recent Advances in Parkinson's disease. Philadelphia: FA Davis, 1971;pp. 131-161.

45. Boller F, Mizutani T, Roessmann V, Gambetti P. Parkinson disease, dementia, and Alzheimer disease: clinicopathological correlations. Ann Neurol 1980; 7: 329-335.

46. Steele JC, Richardson JC, Olszewski J. Progressive supranuclear palsy. Arch Neurol 1964; 10: 333-359.

47. Chen L. Neurofibrillary change on Guam. Arch Neurol 1981;38: 16-18.

48. Wisniewski K, Jervis GA, Moretz RC, Wisniewski HM. Alzheimer neurofibrillary tangles in diseases other than senile and presenile dementia. Ann Neurol 1979; 5 : 288-294.

49. Corsellis JAN, Bruton CJ, Freeman-Browne D. The aftermath of boxing. Psychol Med 1973; 3: 270-303.

50. Uhl GR, McKinney M, Hedreen JC, White III CL, Coyle JT, Whitehouse PJ, Price DL. Dementia pugilistica: loss of basal forebrain cholinergic neurons and cortical cholinergic markers. Ann Neurol 1982; 12: 99.

51. Bowen DM, Smith CB, White P. Davison AN. Neurotransmitterrelated enzymes and indices of hypoxia in senile dementia and other abiotrophies. Brain 1976; 99: 459-496.

52. Davies P. Neurotransmitter-related enzymes in senile dementia of the Alzheimer type. Brain Res 1979; 171: 319-327.

53. Richter JA, Perry EK, Tomlinson BE. Acetycholine and choline levels in post-mortem human brain tissue: preliminary observations in Alzheimer's disease. Life Sci 1980; 26: 1683-1689.

54. Perry EK, Tomlinson BE, Blessed G, Perry RH, Cross AJ, Crow TJ. Neuropathological and biochemical observations on the noradrenergic system in Alzheimer's disease. J Neurol Sci 1981 ; 51: $279-287$.

55. Rossor MN. Dementia. Lancet 1982; 2: 1220-1204.

56. Gottfries C-G, Adolfsson R, Aquillonius S-M, Carlsson A, Eckernäs S-A, Nordberg A, Oreland L, Svennerholm L, Wiberg A, Winblad B. Biochemical changes in dementia disorders of Alzheimer type (AD/SDAT). Neurobiol Aging 1983; 4: 261-271.

57. McGeer PL, McGeer EG, Suzuki J, Dolman CE, Nagai T. Aging, Alzheimer's disease, and the cholinergic system of the basal forebrain. Neurology (Cleveland) 1984; 34: 741-745.

58. DeKosky ST, Scheff SW, Markesbery WR. Laminar organization of cholinergic circuits in human frontal cortex in Alzheimer's disease and aging. Neurology 1985; 35: 1425-1431.

59. Perry E, Curtis M, Dick DJ, Candy JM, Atack JR, Bloxham CA Blessed G, Fairbairn A, Tomlinson BE, Perry RH. Cholinergic correlates of cognitive impairment in Parkinson's disease: Comparisons with Alzheimer's disease. J Neurol Neurosurg Psychiatry $1985 ; 48: 413-421$.

60. Davies P, Verth AH. Regional distribution of muscarinic acetylcholine receptor in normal and Alzheimer's-type dementia brains. Brain Res 1978; 138: 385-392.

61. Bartus RT, Dean RL, Beer B, Lippa AS. The cholinergic hypothesis of geriatric memory dysfunction. Science 1982:217: 408-417.

62. Cross AJ, Crow TJ, Ferrier IN, Johnson JA, Markkagis D. Striatal dopamine receptors in Alzheimer-type dementia. Neurosci Lett 1984; 52: 1-6

63. Adolfsson R, Gottfries CG, Roos BE, Winblad B. Changes in brain catecholamines in patients with dementia of Alzheimer's type. Br J Psychiatry 1979; 135: 216-223.
64. Rossor MN, Emson PC, Mountjoy CQ, Roth M, Iversen LL. Reduced amounts of immunoreactive somatostatin in the temporal cortex in senile dementia of Alzheimer type. Neurosci Lett 1980; 20: 373-377.

65. Carlsson A. Aging and brain neurotransmitters. In: Cook T, Gershen $S$ (Eds.), Strategies for the Development of an Effective Treatment for Senile Dementia. New Canaan, Mark Powley 1981; pp. 93-104.

66. Winblad B, Adolfsson R, Carlsson A, Gottfries C-G. Biogenic amines in brains of patients with Alzheimer's disease. In: Gorkin S, Davis KL, Growdon JH, Usdin E, Wurtman RJ (Eds.) Alzheimer's disease: a report of progress in research. Aging Vol 19. New York, Raven Press, 1982; pp. 25-33.

67. Gibson CJ, Ball MJ. Hippocampal monoamine deficits in Alzheimer's disease. J Neurochem 1983; Suppl 41: S20B.

68. Bondareff W, Mountjoy CQ, Roth M. Loss of neurons of origin of the adrenergic projection to cerebral cortex (nucleus locus ceruleus) in senile dementia. Neurology (NY) 1982; 32: 164-168.

69. Carlsson A, Adolfsson R, Aquilonius S-M, Gottfries C-H, Oreland $\mathrm{L}$, et al. Biogenic amines in human brain in normal aging, senile dementia, and chronic alcoholism. In: Goldstein $\mathrm{M}$ et al (Eds.). Ergot Compounds and Brain Function: Neuroendocrine and Neuropsychiatric Aspects. New York, Raven, 1980; pp. 95-304.

70. Gottfries CG, Gottfries I, Roos BE. The investigation of homovanillinic acid in human brain and its correlation to senile dementia. Br J Psychiatry 1969; 115: 563-574.

71. Yates CM, Allison Y, Simpson J, Maloney AFJ, Gordon A. Dopamine in Alzheimer's disease and senile dementia. Lancet 1979; 2: 851-852.

72. Bareggi SR, Franceschi M, Bonnini L, Zecca L, Smirne S. Decreased CSF concentration of homovanillic acid and $y$-aminobutyric acid in Alzheimer's disease. Arch Neurol 1982; 39: 709-712.

73. Soininen H, Macdonald E, Rekonen M, Riekkinen PJ. Homovanillic acid and 5-hydroxyindoleacetic acid levels in cerebrospinal fluid of patients with senile dementia of Alzheimer type. Acta Neurol Scand $1981 ; 64: 101-107$.

74. Palmer AM, Sims NR, Bowen DM, Neary D, Palo J, Wikstrom J, Davison AN. Monoamine metabolite concentrations in lumbal cerebrospinal fluid of patients with histologically verified Alzheimer's dementia. J Neurol Neurosurg Psychiatry 1984; 47: 481-484.

75. Cross AJ, Crow TJ, Perry EK, Perry RH, Blessed G, Tomlinson BE. Reduced dopamine-beta-hycroxylase activity in Alzheimer's disease. Brit Med J 1981; 282: 93-94.

76. Reisine TD, Yamamura HI, Bird ED, Spokes E, Enna SJ. Preand postsynaptic neurochemical alterations in Alzheimer's disease. Brain Res 1978; 159: 477-481.

77. Cross AJ, Crow TJ, Ferrier IN, Johnson JA, Bloom SR, Corsellis JAN. Serotonin receptor changes in dementia of the Alzheimer type. J Neurochem 1984; 43: 1574-1581.

78. Davies P, Katzman R, Terry RD. Reduced somatostatin-like immunoreactivity in cerebral cortex from cases of Alzheimer disease and Alzheimer senile dementia. Nature 1980;288: 279-280.

79. Beal MF, Mazurek MF, Chatta G, Bird ED, Martin JB, Reduced numbers of somatostatin receptors in the cerebral cortex in Alzheimer's disease. Science 1985; 229: 289-291.

80. Roberts GW, Crow TJ, Polak JM. Location of neuronal tangles in somatostatin neurones in Alzheimer's disease. Nature 1985; 314: 92-94.

81. Morrison JH, Rogers J, Scherr S, Benoit R, Bloom FE. Somatostatin immunoreactivity in neuritic plaques of Alzheimer's patients. Nature $1985 ; 314: 90-93$.

82. Rossor MN, Emson PC, Iversen LL, Mountjoy CQ, Roth M, Fahrenkrug J, Rehfeld JF. Neuropeptides and neurotransmitters in cerebral cortex in Alzheimer's disease. In: Corkin S, Davis L, Growdon JH, Usdin E, Wurtman RJ(Eds). Alzheimer's disease: A report of progress, Ageing Vol 19, New York, Raven 1982; pp. 15-24.

83. Rossor MN, Garrett NJ, Johnson AL, Mountjoy CQ, Roth M, Iversen LL. A post-mortem study of the cholinergic and GABA systems in senile dementia. Brain 1982; 105: 313-330.

84. Yates CM, Harmer AJ, Rosie R, et al. Thyrotropin-releasing hormone, luteinizing hormone-releasing hormone and substance $\mathrm{P}$ immunoreactivity in post-mortem brains from cases of Alzheimer- 
type dementia and Down's syndrome. Brain Res 1983; 258 45-52.

85. Davies $\mathbf{P}$, Terry RD. Cortical somatostatin-like immunoreactivity in cases of Alzheimer's disease and senile dementia of Alzheimer type. Neurobiol Ageing 1981; 2: 9-14.

86. Perry EK, Atack JR, Perry RH, Hardy JA, Dodd PR, Edwardson JA, Blessed G, Tomlinson BE, Fairbarn AF. Intralaminar neurochemical distributions in human midtemporal cortex: comparison between Alzheimer's disease and normal. J Neurochem 1984; 42: 1402-1410.

87. Francis PT, Palmer AM, Sims NR, Bowen DM, Davison AN, Esiri MM, Neary D, Snowden JS, Wilcock GK. Neurochemical studies of early-onset Alzheimer's disease. N Engl J Med 1985; 313: 7-11.

88. Mayeux R, Stern Y, Spanton S. Heterogeneity in dementia of the Alzheimer type: Evidence of subgroups. Neurology 1985; 35: 453-461

89. McKhann G, Drachman D, Folstein M, Katzman R, Price D, Stadlan EM. Clinical diagnosis of Alzheimer's disease: Report of the NINCDS-ADRDA Work Group under the auspices of the Department of Health and Human Services Task Force on Alzheimer's disease. Neurology 1984; 34: 939-944.

90. Mölsä PK, Marttila RJ, Rinne UK. Extrapyramidal signs in Alzheimer's disease. Neurology (Cleveland) 1984;34: 1114-1116.

91. Aikawa H, Suzuki K, Iwasaki Y, Izuka R. Atypical Alzheimer's disease with spastic paresis and ataxia. Ann Neurol 1985; 17 297-300.

92. Huntington G. On chorea. Med Surg Reporter 1872; 26: 317-321.

93. Denny-Brown D. The basal ganglia. London: Oxford University Press 1962.

94. Bruyn GW. Huntington's chorea: historical, clinical and laboratory synopsis. In: Vinken PJ, Bruyn GW (Eds.), Handbook of Clinical Neurology. Vol 6. Amsterdam: North Holland, 1968; pp. 298-378.

95. Starr A. A disorder of rapid eye movements in Huntington's chorea. Brain 1967; 90: 545-564.

96. McDowell FH, Lee EJ, Sweet RD. Extrapyramidal disease. In: Baker AB, Baker LH (Eds.), Clinical neurology. New York: Harper 1978; pp. 1-67.

97. Sax DS, Myers RH, Wolf PA, Bird ED, Schoenfeld M. Late onse Huntington disease. Neurology 1982; 32: A186.

98. Meyers RM, Goldman D, Bird ED, Sax DS, Merril CR, Schoenfeld M, Wolf PA. Maternal transmission in Huntington's disease. Lancet 1983; 1: 208-210.

99. Bird MT, Paulson GW. The rigid form of Huntington's chorea. Neurology 1971; 21: 271-276.

100. Low PA, Allsop JL, Halmagyi GM. Huntington's chorea: the rigid form (Westphal variant) treated with levodopa. Med J Aust 1974; 1: 393-394.

101. Oliver J, Dewhurst K. Childhood and adolescent forms of Huntington's disease. J Neurol Neurosurg Psychiatry 1969; 32 455-459.

102. Byers RK, Gilles FH, Fung C. Huntington's disease in children Neurology 1973; 23: 561-569.

103. Mayeux R, Stern Y. Emotional changes associated with basal ganglia disorders. In: Heilman K, Satz P (Eds.), The Neuropsychology of Human Emotion. New York: Guilford Press, 1983.

104. Reed TE, Chandler JH, Hughes EM, Davidson RT. Huntington's chorea in Michigan. I. Demography and genetics. Am J Hum Genet 1958; 10: 201-225.

105. Folstein SE, Folstein MF, McHugh PR. Psychiatric syndromes in Huntington's disease. Adv Neurol 1979; 23: 281-289.

106. Lieberman A, Dziatolowski M, Kupersmith M, Serby M, Goodgold A, Korein J, Goldstein M. Dementia in Parkinson disease. Ann Neurol 1979; 6: 355-359.

107. Lieberman A, Dziatolowski M, Neophytides A, et al. Dementias of Huntington's and Parkinson's disease. Adv Neurol 1979; 23: 273-280.

108. Caine ED, Shoulson 1. Psychiatric syndromes in Huntington's disease. Am J Psychiatry 1983; 140: 728-733.

109. Brothers C. Huntington's chorea in Victoria and Tasmania. J Neurol Sci 1964; 1: 405-420.

110. Lyle OE, Gottesman II. Subtle cognitive deficits as 15-to-20 year precursors of Huntington's disease. In: Chase TN, Wexler NS,
Barbeau A (Eds.), Advances in Neurology, vol 23, New York: Raven Press, 1979; pp. 227-238.

111. Dewhurst K, Oliver JE, McKnight AL. Socio-psychiatric consequences of Huntington's disease. Br J Psychiatry 1970; 116 255-258.

112. Trimble M. (Ed) Neuropsychiatry. New York: John Wiley and Sons, 1981

113. Fedio P, Cox CS. Neophytides A, Ghislane CF, Chase TN. Neuropsychological profile of Huntington's disease: Patients and those at risk. In: Chase TN, Wexler NS, Barbeau A (Eds.), Advances in Neurology, vol 23, New York: Raven Press, 1979; pp. 239-255.

114. Weingartner H, Caine ED, Ebert MH. Encoding processes. Learning and recall in Huntington's disease. $I n$ : Chase TN, Wexler NS, Barbeau A (Eds.). Advances in Neurology, vol 23, New York: Raven Press 1979; pp. 215-226.

115. Albert MS, Butters N, Brandt J. Patterns of remote memory in amnesic and demented patients. Arch Neurol 1981; 38: 495-500.

116. Fisher JM, Kennedy JL, Caine ED, Shoulson I. Dementia in Huntington disease: A cross-sectional analysis of intellectual decline. In: Mayeux R, Rosen WG (Eds.), New York, Raven Press 1983; pp. 229-238.

117. Rosen WG. Clinical and neuropsychological assessment of Alzheimer disease. In: Mayeux R, Rosen WG (Eds.), The Dementias. New York, Raven Press, 1983; pp. 51-64

118. Sax DS, O'Donnell L, Butters N, Menzer L, Montgomery K, Kayne HL. Computed tomographic, neurologic, and neuropsychological correlates of Huntington's disease. Intern J Neurosci 1983; 18: 21-36.

119. Fuld PA. Test profile of cholinergic dysfunction and of Alzheimertype dementia. J Clin Neuropsych 1984; 6: 380-392.

120. Aminoff MJ, Marshall J, Smith EM, Wyke MA. Pattern of intellectual impairment in Huntington's chorea. Psychol Med 1975; 5 : 169-172.

121. Haymaker W, Mehler WF, Schiller F. Extrapyramidal motor disorders. In: Haymaker W (Ed.), Bing's local diagnosis in neurological diseases. 15th ed. St. Louis: CV Mosby 1969; pp. 404-440.

122. Terrence CF, Delaney JF, Alberts MC. Computed tomography for Huntington's disease. Neuroradiology 1977; 13: 173-175.

123. Neophytides AN, DiChiro G, Barron SA, Chase TN. Computed axial tomography in Huntington's disease and persons at risk for Huntington's disease. Adv Neurol 1979; 23: 185-191.

124. Dreese MJ, Netsky MG. Degenerative disorders of the basal ganglia. In: Minckler J (Ed.), Pathology of the nervous system. New York: McGraw-Hill 1968; pp. 1185-1204.

125. Lange H, Thörner G, Hopf A, Shröder KF. Morphometric studies of the neuropathological changes in choreatic diseases. J Neurol Sci 1976; 28: 401-425.

126. Dom R, Malfroid M, Baro F. Neuropathology of Huntington's chorea. Studies of the ventrobasal complex of the thalamus. Neurology 1976; 26: 64-68.

127. Bruyn GW, Bots GTAM, Dom R. Huntington's chorea: current neuropathological status. In: Chase TN, Wexler NS, Barbeau A (Eds.), Advances in neurology, vol 23, New York: Raven Press 1979; pp. 83-94.

128. Roos RAC, Pruyt JFM, de Vries J, Both GTAM. Neuronal distribution in the putamen in Huntington's disease. J Neurol Neurosurg Psychiatry 1985; 48: 422-425.

129. Bugiani O, Tabaton M, Cammarata S. Huntington's disease: survival of large striatal neurones in the rigid variant. Ann Neurol 1984; 15: 154-156.

130. McCaughley WTE. The pathologic spectrum of Huntington's chorea. J Nerv Ment Dis 1961: 133: 91-103.

131. Bird ED, Mackay AVP, Rayner CN, Iversen LL. Reduced glutamicacid-decarboxylase activity in post-mortem brain in Huntington's chorea. Lancet 1973; 1: 1090-1092.

132. McGeer PL, McGeer EG, Fibiger HC. Cholineacetylase and glutamic acid decarboxylase in Huntington's chorea. A preliminary study. Neurolog (Minneap.) 1973; 23: 912-917.

133. Perry TL, Hansen S, Kloster M. Huntington's chorea - deficiency of y-aminobutyric acid in brain. New Engl J Med 1973; 288: 337-342.

134. Bird ED, Iversen LL. Huntington's chorea-postmortem measurement of glutamic acid decarboxylase, choline asetyl transferase 
and dopamine in basal ganglia. Brain 1974; 97: 457-472.

135. Urquhart N, Perry TL, Hansen S, Kennedy J. GABA content and glutamic acid decarboxylase activity in brain of Huntington's chorea patient and control subjects. J Neurochem 1975; 24: 1071-1075.

136. Bird ED. Biochemical studies on y-aminobutyric acid metabolism in Huntington's chorea. In: Bradford HF, Marsden CD (Ed.), Biochemistry and Neurology. New York: Academic Press. 1976; pp. 83-92.

137. Sourkes TL. Parkinson's disease and other disorders of the basal ganglia. In: Siegel GJ, Alberts RW, Katzman R, Agranoff BW (Eds.), Basic Neurochemistry. 2nd ed. Boston: Little, Brown, 1976; pp. 668-684.

138. Enna SJ, Stern LZ, Wastek GJ, Yamamura HI. Cerebrospinal fluid $\mathrm{y}$-aminobutyric acid variations in neurological diseases. $\mathrm{N}$ Engl J Med 1977; 34: 683-685.

139. Bala Manyam NV, Hare TA, Katz L, Glaeser BS. Huntington's disease. Cerebrospinal fluid GABA levels in at-risk individuals. Arch Neurol 1978; 35: 728-730.

140. Perry TL, Wright JM, Hansen S, Thomas SMB, Allan BM, Baird PA, Diewold MA. A double-blind clinical trial of izoniazid in Huntington disease. Neurology (Ny) 1982; 32: 354-358.

141. Van Ness PC. Watkins AE. Bergman MO, Tourtelotte WW, Olsen RW. y-aminobutyric acid receptors in normal human brain and Huntington disease. Neurology (Ny) 1982; 32: 63-68.

142. Stahl WL, Swanson PD. Biochemical abnormalities in Huntington's chorea brains. Neurology 1974; 24: 813-819.

143. Wu JY, Bird ED, Chen MS, Huang WM. Studies of neurotransmitter enzymes in Huntington's chorea. Adv Neurol 1979;23: 527-536.

144. Spokes EGS. Dopamine in Huntington's disease; a study of postmortem brain tissue. Adv Neurol 1979; 23: 481-493.

145. Melamed E, Hefti F, Bird ED. Huntington chorea is not associated with hyperactivity of nigrostriatal dopaminergic neurons: Studies in postmortem brain tissues and in rates with kainic acid lesions. Neurology (Ny) 1982; 32: 640-644.

146. Kuhl DE, Phelps ME, Markham CH, Metter EJ, Riege WH, Winter J. Cerebral metabolism and atrophy in Huntington's disease determined by 18 FDG and computed tomographic scan. Ann Neurol 1982; 425-434.

147. Hayden MR, Martin WRW, Stoess! AJ, et al. Positron emission tomography in the early diagnosis of Huntington disease. Neurology 1986 (in press).

148. Stoessl AJ, et al. In preparation. Figure 2. 1986.

149. Metter EJ, Riege WH, Kameyama M, Kuhl DE, Phelps ME. Cerebral metabolic relationships for selected brain regions in Alzheimer's, Huntington's and Parkinson's diseases. JCBF Metab 1984; 4: 500-506.

150. Aronin N, Cooper PE, Lorenz LJ, Bird ED, Sagar SM, Leeman $\mathrm{SE}$, Martin JB. Somatostatin is increased in the basal ganglia in the Huntington's disease. Ann Neurol 1983; 13: 519-526.

151. Kanazawa I, Bird E, O'Connell R, Powell D. Evidence for a decrease in substance $P$ content of substantia nigra in Huntington's chorea. Brain Res 1977; 120: 387-392.

152. Arrequi A, Bennett JP, Bird ED, Yamamusa HI, Iversen LL, Snyder SH. Huntington's chorea: selective depletion of activity of angiotensin converting enzyme in the corpus striatum. Ann Neurol 1977; 2: 294-298.

153. Emson PC, Rossor MN, Hunt SP, et al. Distribution and postmortem stability of substance $P$, met-encephalin, vasoactive intestinal polypeptide and cholecystokinin in normal human brain and Huntington's disease. In: Rose FC (Ed.) Metabolic Disorders of the Nervous System. Pitman, Marshfield 1981; pp. 312-321.

154. Pittaway KM, Reynolds GP, Emson PC. Decreased proline endopeptidase activity in basal ganglia in Huntington's disease. J Neurochem 1984; 43: 878-880.

155. Marshall PE, Landis DM. Huntington's disease is accompanied by changes in the distribution of somatostatin-containing neuronal processes. Brain Res 1985; 329: 71-82.

156. Martin WE, Resch JA, Baker AB. Juvenile parkinsonism. Arch Neurol 1971; 25: 494-500.

157. Spellınan GG. Report of familiar cases of parkinsonism. JAMA 1962; 179: 160-162.

158. Kuhl DE, Metter EJ, Riege WH. Patterns of local cerebral glucose utilization determined in Parkinson's disease by the (18F) fluorodeoxyglucose method. Ann Neurol 1984; 15: 419-424.
159. Martin WRW, Stoessl AJ, Adam MJ, Ammann W, Bergstrom M, Harrop R, Laihinen A, Rogers JG, Ruth TJ, Sayre C, Pate BD, Calne DB. Positron emission tomography in Parkinson's disease: glucose and dopa metabolism. Adv Neurol 1986 (in press).

160. Pollock M, Hornabrook RW. The prevalence, natural history and dementia of Parkinson's disease. Brain 1966; 89: 429-448.

161. Mindham RHS. Psychiatric symptoms in parkinsonism. J Neurol Neurosurg Psychiatry 1970; 213: 456-466.

162. Martin WE, Loewenson RB, Resch JA, Baker AB. Parkinson's disease. Clinical analysis of 100 patients. Neurology 1973; 23: 783-790.

163. Marttila RJ, Rinne UK. Dementia in Parkinson's disease. Acta Neurol Scand 1976; 54: 431-441.

164. Sweet RD, McDowell FH, Ferguson JS, Loranger AW, Goodell H. Mental symptoms in Parkinson's disease during chronic treatment with levodopa. Neurology 1976; 26: 305-310.

165. Hakim AM, Mathieson G. Dementia in Parkinson disease: a neuropathological study. Neurology 1979; 29: 1209-1214.

166. DeSmet Y, Ruberg M, Serdaru M, Dubois B, Lhermitte F, Agid $Y$. Confusion, dementia and anticholinergics in Parkinson's disease. J Neurol Neurosurg Psychiatr 1982; 45: 1161-1164.

167. Rajput AH, Offord K, Bard MC, Kurland LT. Epidemiological survey of dementia in parkinsonism and control population. I $n$ : Hassler RG, Christ JF (Eds.), Advances in Neurology, vol 40 1984; pp. 229-234.

168. Mjönes H. Paralysis agitans, a clinical and genetic study. Acta Psychiatr Neur (Suppl) 1949; 54: 1-195.

169. Pirozzolo FJ, Hansch EC, Mortimer JA, Webster DD, Kuskowski MA. Dementia in Parkinson disease. A neuropsychological analysis. Brain and Cognition 1982; 1: 71-83.

170. Mortimer JA, Pirozzolo FJ, Hansch EC, Webster DD. Relationship of motor symptoms to intellectual deficits in Parkinson's disease. Neurology (Ny) 1982; 32: 133-137.

171. Matthews CG, Haaland KY. The effect of symptom duration on cognitive and motor performance in parkinsonism. Neurology 1979; 29: 951-956.

171a. Elizan TS, Sroka H, Maker H, Smith H, Yahr MD. Dementia in idiopathic Parkinson's Disease. Neuro Trans 1986; 65: 285-302.

172. Brown RG, Marsden CD. How common is dementia in Parkinson's disease. Lancet 1984; ii: 1262-1265.

173. Lees AJ. Parkinson's disease and dementia. Lancet 1985; i: 43-44.

173a. Freedthan M, Oscar-Berman M. Selective delayed response deficits in Parkinson's and Alzheimer's Disease. Arch Neurol. 1986 (in press).

174. Mayeux R, Stern Y, Rosen J, Leventhal J. Depression, intellectual impairment, and Parkinson disease. Ann Neurol 1981; 31: 645-650.

175. Koller WC. Disturbance of recent memory function in Parkinsonian patients on anticholinergic therapy. Cortex 1984; 20:307-311.

176. Hoehn MM, Yahr MD. Parkinsonism, onset, progression and mortality. Neurology (Minneapolis) 1967; 17: 427-442.

177. Kogi K: Significance of flicker test in industrial fatigue research with special reference to activating system of the brain. Rep Instit Sci Lab 1961; 58: 37-53.

178. Lees AJ, Smith E. Cognitive deficits in the early stages of Parkinson's disease. Brain 1983; 106: 257-270.

179. Levita E, Riklan M, Cooper IS. Cognitive and perceptual performance in parkinsonism as a function of age and neurological impairment. J Nerv Ment Dis 1964; 139: 516-520.

180. Garron. DC, Klawans HL, Narin F. Intellectual functioning of persons with idiopathic parkinsonism. J Nerv Ment Dis 1972; 154: $445-451$.

181. Lieberman AN. Parkinson's disease: a clinical review. Am J Med Sci 1974; 267: 66-80.

182. Loranger AW, Goodell H, McDowell F, Lee JE, Sweet RD. Intellectual impairment in Parkinson's syndrome. Brain 1972; 95: 405-412.

183. Levita E, Riklan M. Integrative functions in parkinsonism. Perc Motor Skills 1970; 31: 379-385.

184. Selby G. Cerebral atrophy in Parkinsonism. J. Neurol Sci 1968; 6 : 517.559 .

185. Alvord EC. The pathology of Parkinsonism. Part II. An interpretation with special reference to other changes in the aging brain. In: McDowell FC, Markham CH (Eds.) Recent Advances in Parkinson's disease. Philadelphia: FA Davis, 1971; pp. 131-161. 
186. Sroka H, Elizan TS, Yahr MD, Burger A, Medazu MR. Organic mental syndrome and confusional states in Parkinson's disease. Arch Neurol 1981; 38: 339-342.

187. Oppenheimer DR. Diseases of the basal ganglia, cerebellum, and motor neurons. In: Blackwood W, Corsellis JAN (Eds.) Greenfield's Neuropathology. Chicago: Year Book Medical Publishers, 1976; pp. 608-651.

188. Langston JW, Forno LS. The hypothalamus in Parkinson disease. Ann Neurol 1978; 3: 12-133.

189. Javoy-Agid F, Agid $Y$. Is the mesocortical dopaminergic system involved in Parkinson disease? Neurology 1980; 30: 1326-1330.

190. Hassler R. Zur Pathologie der Paralysis agitans und des postencephalitischen Parkinsonismus. J Psychol u Neurol 1938; 8: 387-476.

191. Den Hartog Jager WA, Betlehem J. The distribution of Lewy bodies in the central and autonomic nervous system in idiopathic paralysis agitans. J Neurol Neurosurg Psychiat 1960;23: 283-290.

192. Alvord EC, Forno LS, Kusske JA, Kauffman RJ, Rhodes JS, Goetowski CR. The pathology of parkinsonism: a comparison of degenerations in cerebral cortex and brainstem. Adv Neurol 1975; 5: 175-193.

193. Mann DMA, Yates PO. Pathological basis for neurotransmitter changes in Parkinson's disease. Neuropath Appl Neurobiol 1983; 9: 3-19.

194. Ball MJ. The morphological basis of dementia in Parkinson's disease. Can J Neurol Sci 1984; 11: 180-184.

195. Heston LL, Mastri AR, Anderson VE, White J. Dementia of the Alzheimer type: clinical genetics, natural history and associated conditions. Arch Gen Psychiatry 1981; 38: 1085-1090.

196. Perry RH, Tomlinson BE, Candy JM, Blessed G, Foster JF, Bloxham CA, Perry EK. Cortical cholinergic deficit in mentally impaired parkinsonian patients. Lancet 1983; 2: 789-790.

197. Heilig CW, Knopman DS, Mastri AR, Frey W II. Dementia without Alzheimer pathology. Neurology 1985; 35: 762-765.

198. Whitehouse PJ, Hedreen JC, White CL, Price DL. Basal forebrain neurons in the dementia of Parkinson's disease. Ann Neurol 1983; 13: 243-248.

199. Candy JM, Perry RH, Perry EK, Irving D, Blessed G, Fairbairn $\mathrm{AF}$, Tomlinson BE. Pathological changes in the nucleus of Meynert in Alzheimer's and Parkinson's disease. J Neurol Sci 1983; 59: 277-289.

200. Price KS, Farley IJ and Hornykiewicz O. Neurochemistry of Parkinson's disease: relation between striatal and limbic dopamine. Adv Biochem Pharmacol 1978; 19: 293-300.

201. Beart PM. Transmitters and receptors in the basal ganglia. In: McKenzie JS, Kemm RE, Wilcock LN (Eds.) The Basal Ganglia. New York, Plenum Press. 1984; pp. 261-296.

202. Scatton V, Javoy-Agid F, Rouquir L, Dubois B, Agid Y. Reduction of cortical dopamine, noradrenaline, serotonin and their metabolites in Parkinson's disease. Brain Res 1983; 275-328.

203. Hornykiewicz O. Brain transmitter changes in Parkinson's disease. In: Marsden CD, Fahn S (eds). Neurology ll. Movement Disorders. London: Butterworths 1982; pp. 41-58.

204. Hornykiewicz $O$. Imbalance of brain monoamines and clinical disorders. Progr Brain Res 1982; 55: 419-429.

205. Rinne UK, Sonninen V. Brain catecholamines and their metabolites in Parkinsonian patients. Arch Neurol 1973; 28: 107-110.

206. Farley IJ, Hornykiewicz O. Noradrenaline in subcortical brain regions of patients with Parkinson's disease and control subjects. In: Birkmayer W, Hornykiewicz O (Eds.), Advances in Parkinsonism. Basel: Editiones Roche, 1976; pp. 178-185.

207. Riederer P, Birkmayer W, Seeman D, Wuketich S. Brain noradrenaline and 3-methoxy-4-hydroxyphenylglycol in Parkinson's syndrome. J Neur Transm 1977; 41: 241-246.

208. Mayeux R, Stern Y, Cote L, Williams JBW. Altered serotonin metabolism in depressed patients with Parkinson's disease. Neurology (Cleveland) 1984; 34: 642-646.

209. Ruberg M, Ploska A, Javoy-Agid F, Agid Y. Muscarinic binding and choline acetyltransferase activity in parkinsonian subjects with reference to dementia. Brain Res 1982; 232: 129-139.

210. Epelbaum J, Ruberg M, Moyse ME, Javoy-Agid F, Dubois B, Agid Y. Somatostatin and dementia in Parkinson's disease. Brain Res 1983; 278: 376-379.

211. Kuhl DE, Metter EJ, Benson DF, Ashford JW, Riege WH, Fujikawa DG, Markham CH, Mazziotta JC, Maltese A, Dorsey A. Similarities of cerebral glucose metabolism in Alzheimer's and Parkinsonian dementia JCBF Metab. 1985; 5 (Supp. 1): S169-170.

212. Zetusky WJ, Jankovic J, Pirozzolo JF. The heterogeneity of Parkinson's disease. Neurology 1985; 35: 522-526.

213. Bird TB, Strahanan BS, Sumi SM, Raskind M. Alzheimer's disease: choline acetyltransferase activity in brain tissue from clinical and pathological subgroups. Ann Neurol 1983; 14: 284-293.

214. Albert ML, Feldman RG, Willis AL. The 'subcortical dementia' of progressive supranuclear palsy. J Neurol Neurosurg Psychiatry $1974 ; 37: 121-130$

215. Jackson JA, Jankovic J, Ford J. Progressive supranuclear palsy: clinical features and response to treatment in 16 patients. Ann Neurol 1983; 13: 273-278.

216. D'Antona R, Baron JC, Samson Y, Serdaru M, Viader F, Agid Y, Cambier J. Subcortical dementia. Frontal cortex hypometabolism detected by positron tomography in patients with progressive supranuclear palsy. Brain 1985; 108: 785-799.

217. Tagliavini F, Pilleri G, Bouras C, Constantinidis J. The basal nucleus of Meynert in patients with progressive supranuclear palsy. Neurosci Lett 1984; 44: 37-42.

218. Adams RD, van Bogaert $L$, van der Eecken $H$. Striatonigral degeneration. J Neuropath Exp Neurol 1964; 23: 584-608.

219. Rebeiz JJ, Kolodny EH, Richardson EP, Corticodentatonigral degeneration with neuronal achromasia. Arch Neurol 1968; 18: 20-33.

220. Cummings JL, Benson DF (Eds.). Dementia: A Clinical Approach. Stoneham, Butterworth 1983.

221. Talland GA. Cognitive function in Parkinson's disease. J Nerv Ment Dis 1962; 135: 196-205.

222. Asso D. WAIS scores in a group of Parkinson patients. Br J Psychiatry 1969; 115: 555-556.

223. Reitan RM, Boll TJ. Intellectual and cognitive functions in Parkinson's disease. J Consult Clin Psychol 1971; 37: 364-369.

224. Portin R, Rinne UK. Neuropsychological responses of parkinsonian patients to long-term levodopa treatment. In: Rinne UK, Klinger M, Stamm G (Eds.) Parkinson's disease. Current progress, problems and management. Amsterdam, Elsevier/North Holland Biomedical Press. 1980; pp. 271-304.

225. Villardita C, Smirni P, Le Pera F, Zappala G, Nicoletti F. Mental deterioration, visuoperceptive disabilities and constructional apraxia in Parkinson's disease. Acta Neurol Scand 1982; 66: 112-120.

226. Direnfeld LK, Albert ML, Volicer L, Langlais PJ, Marquis J, Kaplan E. Parkinson's disease. The possible relationship of laterality to dementia and neurochemical findings. Arch Neurol 1984; 41: 935-941.

227. Mayeux R, Stern Y. Intellectual dysfunction and dementia in Parkinson's disease. In: Mayeux R, Rosen Y (Eds.) The Dementias. New York, Raven Press 1983; pp. 211-227. 